\title{
Are energy labels good enough for consumers? Experimental evidence on online appliance purchases
}

\section{Giovanna d'Adda}

University of Milan https://orcid.org/0000-0002-2327-8481

\section{Yu Gao}

Peking University https://orcid.org/0000-0001-7519-0062

Massimo Tavoni ( $\square$ massimo.tavoni@polimi.it)

Polytechnic University of Milan

\section{Article}

Keywords: energy labels, online appliance purchases, standard EU labelling, economic-efficiency.

Posted Date: March 19th, 2021

DOI: https://doi.org/10.21203/rs.3.rs-285900/v1

License: (1) This work is licensed under a Creative Commons Attribution 4.0 International License. Read Full License

Version of Record: A version of this preprint was published at Nature Energy on April 7th, 2022. See the published version at https://doi.org/10.1038/s41560-022-01002-z. 


\title{
Are energy labels good enough for consumers? Experimental evidence on online appliance purchases* $^{*}$
}

\author{
Giovanna d'Adda, ${ }^{\text {ii }}$ Yu Gao ${ }^{\mathrm{iii}}$ and Massimo Tavoni iv
}

\begin{abstract}
We evaluate the impact of adding simple, accurate information to energy labels on consumers' purchases through a large-scale field experiment with an online retailer of energy-using durables. In addition to the energy efficiency grades and energy usage information included in the standard EU labelling, we provide energy cost information at different aggregation levels. We find that providing lifetime energy costs leads to greater attention paid to low energy-efficiency class products during the search process and more purchasing, but has little impact on energy consumption in $\mathrm{kWh}$ or total cost of the products being purchased. Our results suggest that although customers do not understand the labels accurately, they still make nearly optimal decisions based on the coarse signals provided by labels. This is encouraging from a policy perspective because labels simplify the decision process and did not hurt economic-efficiency.
\end{abstract}

\footnotetext{
${ }^{*}$ We would like to thank the staff at our partner organization and at Politecnico di Milano for making the project possible. Matteo Fontana provided outstanding research assistance. We are especially grateful to Lorenz Goette for numerous discussions about this project. Hunt Allcott, Jacopo Bonan, Cristina Cattaneo, Massimo Filippini, Nicola Gennaioli, Michael Greenstone, Sébastien Houde and seminar participants at the $38^{\text {th }}$ International Energy Workshop provided helpful comments and discussions. Financial support from E2e and the European Research Council project COBHAM is gratefully acknowledged. This study is registered in the AEA RCT Registry (AEARCTR-0003939) and received IRB approval from the Ethics Committee at Politecnico di Milano (ID 19924).

ii University of Milan, Fondazione Pesenti and RFF-CMCC European Institute on Economics and the Environment (giovanna.dadda@unimi.it). Corresponding author.

iii Guanghua School of Management (GSM), Peking University (ygao@gsm.pku.edu.cn).

iv Politecnico di Milano and RFF-CMCC European Institute on Economics and the Environment (massimo.tavoni@polimi.it).
} 


\section{Introduction}

Labels, certifications, and grades are widely used to provide coarse information signals such as environmental impact, health and safety, and financial risks. They are very powerful in focusing people's attention on the attribute being graded. They are often required by law to help consumers who have limited ability to retrieve, attend to, and understand complex information (Abaluck and Gruber 2011, 2016; Chetty et al. 2009).

An appliance's energy consumption is often non-transparent, highly complex, and the costs associated with it are distributed over time: these features make it less salient than other appliances' attributes, such as price (Bordalo et al. 2013). Failure to provide consumers with salient and accurate energy cost information may lead to suboptimal choices since such information is essential in computing cost-benefit trade-offs. Nevertheless, in practice, information about energy costs is typically given in Europe and elsewhere, through grading systems or certifications, such as stars, letter-grades, and other coarse rankings, rather than through exact estimates of products' energy costs. Indeed, grading systems commonly mandated by policy makers, help consumers make privately optimal decisions and fill the so-called energy-efficiency gap (Gerarden et al. 2017, 2015; Allcott 2016; Caplin and Dean 2015; Gillingham et al. 2009; Gillingham and Palmer 2014). ${ }^{1}$ An implicit belief behind such policies is that detailed information might be ineffective.

In Europe, detailed consumption information is provided in terms of kilowatt-hours $(\mathrm{kWh})$ per year. Translating energy consumption into energy costs requires knowledge of energy prices. As a result, consumers may be reluctant to exert the cognitive effort required to work out appliances' energy costs from information on energy consumption. The grading system provided in addition to the energy consumption information greatly simplifies customers' evaluation of appliances' energy efficiency. However, efficiency classes are imprecisely related to actual energy consumption, due to the relevance of other products' attributes, such as size. In other words, grading systems take into account different product attributes in ways that are not clear to the final user. Therefore, it is possible that detailed cost information could help consumers achieve higher economic efficiency.

We evaluate if grading systems' coarse information is good enough in helping consumers make privately efficient decisions. We conduct a randomized controlled trial (RCT) examining online purchases of large energy-using durables. We focus on refrigerators, one of the most expensive household appliances in terms of price and running costs, the latter being largely independent from usage. ${ }^{2}$ In addition to the grades (A+++, $\mathrm{A}++, \mathrm{A}+$ being the most prevalent ones) and $\mathrm{kWh}$ consumption information included in the EU energy label, experimental treatments provide yearly or lifetime energy cost information. Observing how consumers' decisions change when accurate information is available in a simpler, more

\footnotetext{
${ }^{1}$ On the other hand, the pervasiveness of the energy-efficiency gap is questioned (Allcott and Greenstone 2012).

${ }^{2}$ In Italy, refrigerators are responsible for about $15 \%$ of household energy consumption. Source: Enea (Agenzia Nazionale per le Nuove Tecnologie, l'Energia e lo Sviluppo Tecnologico Sostenibile), available at http://kilowattene.enea.it/KiloWattene-refrigeration-info.html\#.
} 
accessible format will reveal whether consumers rely on coarse signals and whether their private economic efficiency is affected by such reliance.

We partner with a major European online retailer of energy-using durables. Online shopping is a large and rapidly growing market: in $2019,88 \%$ of Europeans reported using the internet, and $63 \%$ made purchases online in the previous 12 months. ${ }^{3}$ This setting gives us access to search as well as purchase data so we can corroborate our findings on decision outcomes with results on the decision-making process.

We find that adding lifetime energy costs information to the coarse signal given by energy labels increases search time and purchases for low energy-class products. However, energy cost information has almost no impact on energy consumption in $\mathrm{kWh}$ or total cost of purchased products. Our results show that although the lifetime energy cost treatment is successful in shifting attention and purchasing decisions, suggesting that consumers took the information into account when making their choices, this shift in attention does not affect the private efficiency of decision outcomes. This is a reassuring finding, given coarse signals' prominence as policy tools for promoting private economic efficiency and environmental sustainability.

Our study is one of the first large-scale RCTs to examine the impact of providing information with different levels of complexity, in the presence of coarse signals on the same attribute, on decisions with large stakes. This allows us to make several original contributions to the literature. First, we observe the impact of information on infra-marginal consumers' actual choices in a real online shopping environment. We observe actual purchases, rather than stated preferences elicited through choice experiments (Davis and Metcalf 2016; Newell and Siikamaki 2014); or products placed in the customer's shopping cart (Deutsch 2010b, 2010a). Second, individuals in our sample are not given a shopping budget or other incentives to make purchases, nor are they approached by sales agents or targeted by specific information (Allcott and Taubinsky 2015; Allcott and Wozny 2013; Boogen et al. 2020). They make decisions in a real shopping environment with minimal demand effects. Third, we observe customers' search processes, which allows us to confirm that the information we provide draws customers' attention.

\section{Theoretical background and related literature}

With empirical evidence dating back to Hausman (1979), there is a long debate on whether consumers are poorly informed or prone to behavioral failures when they trade-off complex product attributes (Allcott 2013; Allcott and Wozny 2013; Chetty et al. 2009; Larrick and Soll 2008). In the domain of energy consumption, failure by individuals to take up privately profitable energy-saving technologies, the so-called energy-efficiency gap, is taken as proof of the presence of such failures and as justification for the provision of information on energy efficiency (Allcott 2016). However, what format such information should take is still a subject of debate.

\footnotetext{
${ }^{3}$ Eurostat 2019 ICT survey; https://ec.europa.eu/eurostat/statistics-explained/index.php/Ecommerce statistics for individuals
} 
On the one hand, researchers justify the provision of information through coarse signals based on the notion of limited attention. Rationally inattentive individuals may choose to act based on incomplete information, rather than incurring costs to become correctly informed (Houde 2018). In the context of purchasing energy-durables, such costs are likely to be high: computing an appliance's lifetime fuel cost requires knowledge of individual discount rates, of the average lifetime of a product and present and future energy prices, together with the ability to calculate present discounted values. Sallee (2014) proposed a theoretical framework to model consumers' rational inattention and uses data on automobiles to show that consumers experience only small welfare losses without detailed information about fuel costs.

On the other hand, providing detailed information affects the adoption of energy-using durables in a wide range of contexts (see Appendix B for a list of studies in this literature). There are two possible mechanisms behind these effects. First, consumers may derive correct information about energy costs from energy labels, but also focus too much attention on the (salient) energy efficiency grades. This may result in consumers preferring products with top efficiency rankings, beyond what is justified by their preferences over energy costs. In this scenario, providing salient and accurate energy cost information may improve decisions' private efficiency by shifting attention from grades to the underlying attribute, cost. Second, consumers may spend too much on energy efficiency in the absence of specific cost information because they overestimate energy costs. ${ }^{4}$ Providing cost information will lead to correctly estimating costs and shift purchases towards products with lower energy consumption in $\mathrm{kWh}$.

Consistent with these theoretical insights, existing evidence shows that labels and grades may have distortionary effects (Darden and McCarthy 2015; Dranove and Jin 2010; Houde 2014; Houde 2018a; Jorion et al. 2005; Newell and Siikamäki 2014; Sammer and Wüstenhagen 2006), and that efficiency gains can result from providing accessible and accurate information to consumers (Davis and Metcalf 2016; Houde 2018b). In particular, Newell and Siikamäki (2014) test various labeling treatments in carefully designed choice experiments: they find that simple information on the economic value of energy savings is the most important element guiding more cost-efficient choices, but that adding a suggestive grade to a model substantially increases the energy efficiency of choices. Despite growing evidence using various methods, the expected effect of adding cost information in a real shopping environment is still ambiguous. Our study aims to fill this gap using an RCT.

Our experimental design, through the provision of energy cost information at two different aggregation levels, also helps disentangle the two above-mentioned mechanisms. If consumers put too much decision weight on the grading system, providing cost information would shift purchases to lower energy-class products. We expect this effect to be stronger when providing lifetime energy costs, since aggregation increases their salience (Bordalo et al. 2013). Alternatively, if cost information works by rectifying consumers' overestimation of electricity prices, then we should observe consumers' purchases shift

\footnotetext{
${ }^{4}$ Empirical support for this hypothesis is provided by Bonan et al. (2019), who conducted a survey of a representative sample of 1500 customers of a major Italian energy utility company and found that respondents' average estimate of the price of a kWh was 0.37 euro, almost twice as much as the actual price (around 0.20 euro).
} 
towards products with lower energy consumption in $\mathrm{kWh}$, with no significant differences between yearly and lifetime cost information.

\section{Experimental design and data}

\section{A. Sample}

We conducted the field experiment between June 1st and October 16th, 2018, on a major Italian online retailer's website. Our sample comprises customers who viewed or purchased a refrigerator from the desktop version of the website throughout the study. For each customer, we have the full navigation history, consisting of one observation per page viewed.

We identify customers primarily through their registration ID, which must be entered to make a purchase, but not to navigate pages, and through cookie-based identification codes, linked to the computer's IP address and browser, which identify customers who are not logged-in (we describe the procedure we use to identify users from these ID codes in Appendix C). We obtain a sample of 128,206 customers viewed a refrigerator page over the study period.

Treatment assignment was performed by cookie-based software routinely used by the online retailer for A/B tests. Each customer visiting the retailer's website for the first time during the study period was randomly assigned to one of three treatments, described below. Therefore, as long as a customer did not clear cookies, she would be exposed to the same treatment on all her subsequent visits. Moreover, once a treatment was associated with a customer ID, it was carried across to other devices or web browsers used by the customer if logged in when starting to browse refrigerator pages. This, however, implies that the same customer could be exposed to multiple treatments if she viewed refrigerators from different computers or laptops without being registered or logged on. This would attenuate any treatment effect we detect, but otherwise should not compromise identification, since the occurrence of such cases should be orthogonal to treatment. Indeed, 7,243 customers in our sample were assigned to multiple treatments; of them, 1,313 made a purchase. In the analysis, we assign these customers to the modal treatment and test the robustness of our results to their exclusion from the sample.

We observe 7,631 single purchases of refrigerators over the study period. For customers who made multiple purchases $(n=290)$, we keep the last, so that we have only one refrigerator purchase per user. ${ }^{5}$ We test the robustness of our results to the exclusion of customers who make multiple purchases. Ruling out multiple treatments and multiple orders results in a sample of 120,779 users and 6,137 purchases.

\section{B. Experimental design}

Customers viewing the website refrigerator pages during the study period were randomly assigned to one of three conditions: (a) the control condition presented the retailer's default product visualization, with information on energy usage in kWh and the EU-label energy-efficiency class; (b) the 1-year condition

\footnotetext{
${ }^{5}$ Multiple purchases are predominantly cases of orders canceled and then re-issued, for instance, following a payment failure due to insufficient funds on a pre-paid card.
} 
added information on the yearly energy usage cost of each product; and (c) the 15-year condition added information on the lifetime energy usage cost of each product.

The energy cost information was provided through a sentence placed next to an icon reproducing the energy class symbol on the energy label. This icon was also present in the control condition. It was aimed at helping customers understand that the information referred to energy costs and reminding them of the product's energy class. The sentence reported the energy usage cost in euro as "Energy costs over 1 year (15 years) will be X euro" in the 1-year (15-year) treatment. We provided the energy cost information in two places on the website: (a) on product listing pages, where products are displayed in a list and the information on a specific product appeared when the customer hovered the mouse over it (see Appendix Figure A1, for a screenshot); and (b) on product pages, where a single product is displayed in detail and the information was placed just below the product image (Figure A2). ${ }^{6}$

The energy cost was calculated by multiplying the yearly energy consumption in $\mathrm{kWh}$, as reported on the product's energy label, by the average unit cost of a kWh, taken from the Italian Authority for Energy, Gas and Water (ARERA) website. ${ }^{7}$ We selected the latest available figure of the residential cost of a $\mathrm{kWh}$, equal to 0.1998 euro in the second quarter of 2018, and computed all energy usage costs applying this same unit cost, undiscounted, to all future periods. The average lifetime of a refrigerator was set at 15 years, based on estimates available from the National Agency for New Technologies, Energy and Sustainable Development (Enea) website. ${ }^{8}$ When computing lifetime energy costs, we simply multiplied yearly costs by average lifetime: while not discounting lifetime energy costs arguably inflates them, we opted to present undiscounted figures to maximize the transparency and simplicity of the information, consistent with the purpose of the study. ${ }^{9}$

The product categories included in the study are free-standing refrigerators (but not minibars) available for delivery during the time of the study. About 2000 products met these criteria in the online retailer's catalogue.

\section{Data}

The analysis relies on the combination of different datasets. The main source of data consists of navigation data, extracted daily from the online retailer. The dataset contains one observation per page visited by users, for all users who visited any page on the retailers' website over the study period. The raw data contains information on the municipality of the user's IP address, details on the page visited, whether the internal search engine was used, the search query text, the time of the page visit and the number of seconds spent viewing the page. If the page viewed by the customer is a product or cart page,

\footnotetext{
${ }^{6}$ In addition, each time the customer clicked on the cost information sentence, a pop-up window explained the nature of the information and the sources of data for the kWh unit cost and refrigerator lifetime (Appendix Figure A3). Since only 0.7\% of users (1.7\% of buyers) clicked to open the pop-up window, in what follows we will not analyze this feature.

7 The information was taken from the following page: https://www.arera.it/it/dati/eep35.htm.

8 The website reports results from a series of engineering studies evaluating the average lifetime of a refrigerator: http://kilowattene.enea.it/KiloWattene-refrigeration-info.html.

${ }^{9}$ This is not very different from discounting at the risk-free interest rate in Italy, which was equal to $1.3 \%$ at the time and would result in multiplying yearly energy costs by 13.54 , instead of 15 , to obtain lifetime costs. Using the risk-free rate would further reduce the cost savings from $\mathrm{A}+++$ products.
} 
then the data also report the product code and whether the product was added to the cart, to the favorites, or ordered.

We collapse the raw data at the user level, creating variables for both purchase and navigation outcomes. For purchases, we record the product's characteristics, including energy class, consumption in kWh, and price. In terms of navigation, the dataset contains information on the total number of refrigerator pages viewed, the total time spent on them in seconds, the number of refrigerator product pages viewed, the number of refrigerators added to the cart, and the favorites, overall and by energy class. ${ }^{10}$ For each user, we also record the modal treatment she was exposed to and the number of other (non-refrigerator) orders she placed. Appendix Table A1 reports summary statistics of available baseline customers' characteristics and shows that they are balanced across treatments. Based on IP addresses, users come from all over the country, with the largest shares from North-Western and central Italy. Our sample is drawn from municipalities with somewhat higher shares of both high school and university graduates, and income levels than national averages. ${ }^{11}$

\section{Figure 1. Refrigerators' lifetime energy cost}

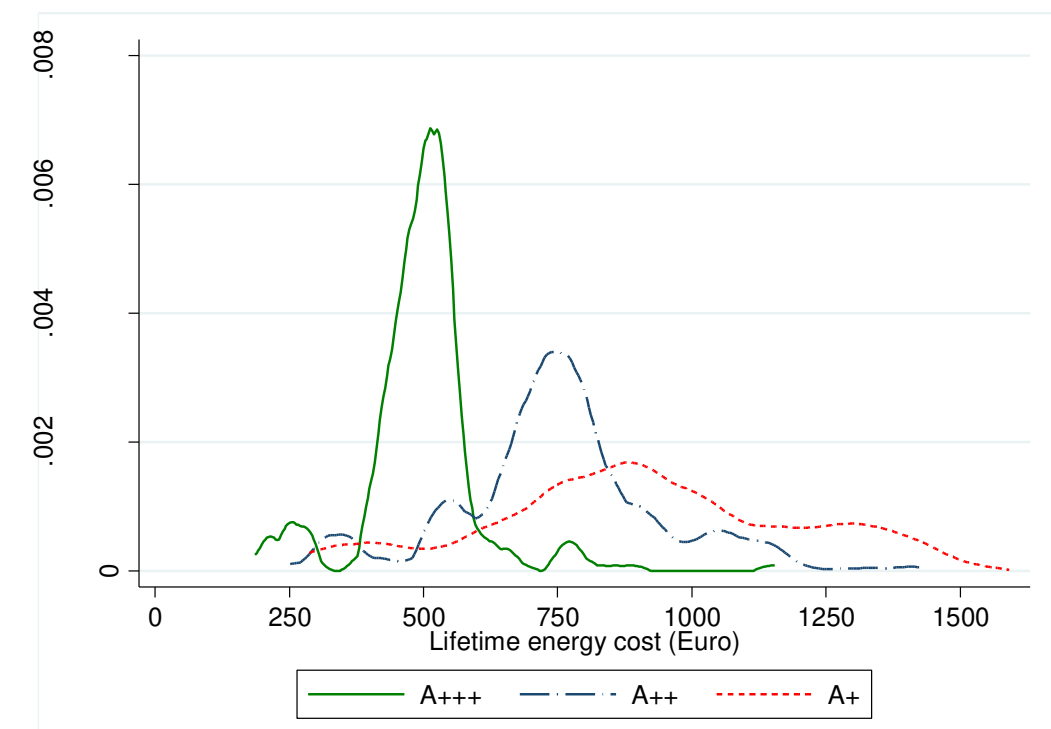

Note: the graph presents the kernel density of lifetime, i.e., 15-year, energy costs of refrigerators included in the retailer's catalogue, by energy class.

The second set of data comes from the product catalogue, and contains information on refrigerators. For each product, identified by the product code, the data reports a description, brand, category (e.g., one door, fridge-freezer, three doors, etc.), energy class, and yearly consumption in $\mathrm{kWh}$, and the corresponding yearly and lifetime energy costs in euro. The majority of products $(50.8 \%)$ are in the A+

\footnotetext{
${ }^{10}$ When collapsing the page-level dataset at the individual level, we correct for multiple observations occurring primarily when customers view their cart, if it contains multiple products: if the cart contains $\mathrm{N}$ products, the dataset features $\mathrm{N}$ rows anytime the user views it, one for each product. In these cases, we assign to each row a value of $1 / \mathrm{N}$ and a time spent on the page equal to the total seconds spent on the cart page divided by $\mathrm{N}$.

${ }^{11}$ Comparison made with the dataset of municipalities from Guiso et al. (2016).
} 
energy class, followed by $\mathrm{A}++(38 \%)$ and $\mathrm{A}+++$ or above $(9.5 \%)$. On average, refrigerators consume $266 \mathrm{kWh}$ of electricity yearly, equivalent to 53 euro, or 798 euro over 15 years. On average, lifetime energy costs decrease as energy class increases, as expected, ranging from 496 euro for A+++ refrigerators, to 750 euro for $\mathrm{A}++$ and 905 euro for $\mathrm{A}+{ }^{12}$ However, Figure 1, by showing large variations in the distribution of energy costs within energy classes, and significant overlaps of energy costs between classes, confirms that the latter are only coarse indicators of the former. This highlights the potential informational benefits from our experimental treatment.

The third dataset contains daily price information for each refrigerator viewed on the website during the study time. That is, for each product viewed, we have the price applied to the product each day from June 1 st to October 16th, plus its shipping price and information on any active promotion on the product on that date. On average, refrigerators cost 660 euro, and prices increase with energy efficiency: A+++ refrigerators cost, on average, almost 300 euro, or 56\%, more than products of energy class A+ (Appendix Table A2). Three main factors determine prices. First, the availability of a product in stock: since the online retailer sells its products and products supplied by other sellers, the product price is the lowest available from suppliers with the product in stock. Second, competitors' prices: for its own products, the online retailer uses an algorithm to automatically match the price charged by competitors for the same product, which results in multiple price updates each day. Third, offers are activated based on a product's category or state: for instance, offers on air conditioners are launched when temperatures rise in late spring, and products returned by customers in good conditions are typically placed on sale. As a result, prices vary greatly over the course of each week: the average difference between the maximum and minimum price for the same product within a week is about $13 \%$ of the average price, corresponding to 107 euro for $\mathrm{A}+++$ refrigerators and 71 euro for $\mathrm{A}+{ }^{13}$

Finally, we have municipal-level data on population, income, education, and other socioeconomic characteristics from Guiso et al. (2016), which we match to the municipality of the user's IP address. In the case of multiple municipalities per user, we consider the modal. We are able to match the retailer's data with the municipality data for 123,022 users. In the analysis, we do not drop customers for whom we have no municipal level information, but code them as coming from an 'unknown' municipality.

\section{Results}

\section{A. Overview of users' behavior}

Out of the 128,206 users in our sample, 43,630 were assigned to the control treatment, 42,654 to the 1year energy cost treatment, and 41,922 to the 15-year energy cost treatment. About $19.74 \%$ of users $(25,304)$ registered or logged into the website at some point. On average, users viewed 10.1 refrigerator pages, ranging between 8.1 for those who did not make a purchase and 42.1 for those who did. This corresponds to an average 734 seconds spent browsing refrigerators, 3,057 (about 51 minutes) among

\footnotetext{
${ }^{12}$ At the time of the study, A+++ minus $10 \%$ and A+++ minus $20 \%$ refrigerators were available, respectively 10 and $20 \%$ more efficient than the average A+++ refrigerator. The catalogue also includes refrigerators of class A, although they could not be sold by law. Given the low frequency of these instances (less than $0.5 \%$ overall), we pool them with A+++ and A+ products and refer to them in the text as $\mathrm{A}+++$ and $\mathrm{A}+$ refrigerators, respectively.

${ }^{13}$ Appendix Figure A4 displays such price variation, by energy class, over the study period.
} 
buyers and 587 (9.8 minutes) among non-buyers. Buyers added, on average, 1.43 products to the cart and 0.2 to the favorites.

Of the 7,631 refrigerator purchases made over the study period, 2,631 are in the control, 2,572 in the 1year and 2,428 in the 15-year treatments. This corresponds to an overall conversion rate of 5.95\%. On average, purchased refrigerators cost 565 euro, about 100 euro, or 14.4\%, less than the average refrigerator viewed on the website and included in the retailer's catalogue. Users therefore appear to select among the products available on the retailer's website, the ones with lower prices. ${ }^{14}$ On the contrary, energy costs do not, on average, decrease from catalogue to purchases: they decrease, by 78 euro, or $8 \%$, for A+ refrigerators, but increase by 45 euro, or almost $10 \%$, for A+++ ones. These patterns suggest that the salience of product prices, and the lack of salience of energy costs, influences users' selection of which products to buy, among the ones displayed on the retailer's website.

Among purchases, $39.94 \%$ were of refrigerators of energy class $\mathrm{A}+, 42.35 \%$ of class $\mathrm{A}++$, and $17.71 \%$ of energy class $\mathrm{A}+++.{ }^{15}$ As energy class rises from $\mathrm{A}+$ to $\mathrm{A}+++$, the price increases, and energy cost decreases. As a result, the average undiscounted total cost, which is a combination of the price and energy cost, is roughly the same for A+++ and A+ refrigerators, 1,260 and 1,220 euro respectively, while it is higher, equal to 1466 euro, for A++ products. ${ }^{16}$ Based exclusively on energy costs, A+++ refrigerators would not be worth it for any household with an annual subjective discount rate above $4.4 \%$, which likely includes most households.

\section{B. Treatment effects on purchase decisions}

We evaluate the direct impact of adding energy cost information to the energy class and energy usage information available by default from the retailer's website and energy label; and the differential direct impact of changing the level of aggregation of the energy cost information on the likelihood of making a purchase and on the characteristics of refrigerators bought. We address these questions by estimating the following linear regression model, with robust standard errors:

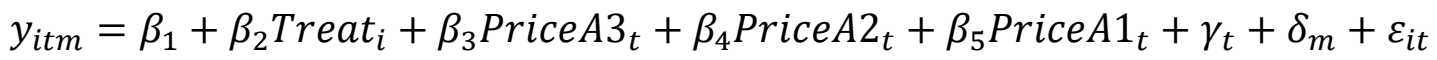

Where $y_{i t m}$ is an outcome for customer $i$, who visited the website's refrigerator pages for the first time at time $t$ and navigated the website primarily from municipality $m$; PriceA $3_{t}$, PriceA2 $t$ and PriceA $1_{t}$ are, respectively, the average price of refrigerators of class $\mathrm{A}+++, \mathrm{A}++$, and $\mathrm{A}+$ on date $t$, divided by $100 ; \gamma_{t}$ are time fixed-effects indicating the week, within which day $t$ falls; and $\delta_{m}$ are municipality fixed-effects. Treat $_{i}$ is treatment status: we first compare treated and control customers, and then distinguish between the 1-year and the 15-year energy cost treatments. When we study the decision to purchase a refrigerator, the sample includes all customers who browsed refrigerator pages, regardless of

\footnotetext{
${ }^{14}$ Indeed, users prefer cheaper products or products on offer: price discounts were applied on $15 \%$ of purchases, while $60 \%$ of purchases benefited from free delivery. Appendix Table A3 provides summary statistics of users' behavior.

${ }^{15}$ We observe 19 purchases of refrigerators of class A, and 4 purchases in each of the A+++ -10\% and A+++ -20\% classes.

${ }^{16}$ Appendix Figure A5 displays the distribution of total cost, by energy class, of purchases in the control condition.
} 
whether they registered with the website or bought a refrigerator. When analyzing the characteristics of products bought, our preferred specifications focus on the sub-sample of customers making a purchase. ${ }^{17}$

Table 1 reports the impact of being treated (Panel A) and each treatment separately (Panel B). Being treated does not affect the overall likelihood that a customer buys a refrigerator (Column 1). This result holds even when we distinguish between the two treatments. This suggests that our sample of buyers consists of customers who would have bought a refrigerator anyway, but whose choice between different products was shifted by the information we provided.

Next, we examine the impact of being treated, and of individual treatments, on the features of purchases. Treated customers tend to buy refrigerators with higher energy consumption, although only the 15-year treatment effect is significant at the $10 \%$ level (Column 2). They also buy cheaper refrigerators (Column 3 ): this effect is small, a reduction of 18.5 euro, or $3.3 \%$, among treated buyers, and statistically significant at the $5 \%$ level overall and the $10 \%$ level for the 15 -year treatment. ${ }^{18}$

We further examine the effect of the energy cost information on the main indicator of private economicefficiency: total cost of purchased refrigerators, which is computed as the sum of sale price and undiscounted lifetime energy cost (Column 4) and find no statistically significant treatment effects. This result is confirmed when we discount energy costs at the risk-free interest rate and at customers' implied discount rate. ${ }^{19}$ The distributions of purchased products' energy costs, prices and total cost confirm that the treatment impact on the energy class of purchases translates to minimal shifts in the distribution of energy costs and prices, resulting in almost identical distributions of total costs by treatment (Appendix Figure A7). The seeming contradiction of significant treatment effects on energy class and only marginally significant effects on energy consumption can also be explained by the imperfect correlation between class and consumption, discussed above. ${ }^{20}$

\footnotetext{
${ }^{17}$ This study is registered in the AEA RCT Registry (AEARCTR-0003939). The registered pre-analysis plan (PAP) was submitted before having access to the full set of cleaned data. The specifications presented here depart from the PAP for the inclusion of the price controls and the consequent replacement of day-fixed effects with week fixed-effects. Including price controls is important to benchmark the effect of information. They are absent from the PAP because, at the time of writing it, we did not know that we could exploit daily variations in prices in the analysis. The PAP analysis is reported in Appendix C: its results are robust to alternative specifications, including dropping price controls and Seemingly Unrelated Regressions (SUR), to deal with the correlation between the outcome variables in regressions of treatment effects on purchases' characteristics. The results are also robust to considering the full sample of users; and to excluding buyers exposed to multiple treatments, or who made multiple purchases (Appendix Table A4).

${ }^{18}$ Sale price information is not available for 90 refrigerators, which explains the drop in the number of observations in Columns 3-4 of Table 1.

${ }^{19}$ Exploiting the daily variation in prices and the detailed information available on customers' navigation history, we estimate an implied discount rate equal to $18 \%$ or $19.8 \%$ : this is very close to the elicitation in Newell and Siikamaki (2015) of $19 \%$ on average. The estimation framework is analogous to the attention weight models in Allcott and Wozny (2013), Newell and Siikamaki (2015), Chetty et al. (2009) and DellaVigna (2009). Appendix D provides further details of the estimation theoretical framework, assumptions and results. Table D2 also reports the treatment effects on total cost when discounting energy costs at the risk free and implied rates.

${ }^{20}$ Appendix Figure A6 displays the marginal treatment effects on energy class, consumption, price and total cost of purchases from the regressions. Appendix Table A5 instead shows that treated customers do not buy smaller refrigerators, measured by capacity in liters.
} 
In terms of the energy class of purchases, treated customers buy fewer of the most efficient products and more of the least efficient ones (Columns 5-7): the treatment effect on the likelihood of purchasing an At++ refrigerator is significant at the 5\% level. This effect is driven by the 15 -year treatment, which increases the share of least efficient purchases by $9.1 \%$, or 3.6 percentage points $(p<0.05){ }^{21}$ The effects of the two treatments are generally not significantly different from each other, except that the 15 -year treatment has a significantly larger impact than the 1-year on the likelihood that customers buy an A+ refrigerator and on the energy consumption of purchases (both $\mathrm{p}<0.1$ ).

Prices correlate with purchases as expected: the likelihood of purchasing a product in a certain energy class depends negatively on the price of products in the same energy class, and positively on the price of products in other energy classes. Specifically, buyers appear to substitute products in higher energy classes (A++ or above) with A+ products, while they do not seem to switch between A+++ and A++ products as their relative prices change. This matches the pattern of our treatments. Comparing the coefficients on the price variables, capturing the effect of a 100 euro increase in prices, to the treatment coefficients indicates that the impact of information on energy costs is economically meaningful: for instance, the effect of being treated on the likelihood that a customer buys an A+++ refrigerator is about half that of a 100 euro increase in their price, while the 15-year treatment has about one-third of the effect of a 100 euro increase in own price on purchases of A+ refrigerators. Both treatment effects are roughly equivalent to the impact of a $6 \%$ increase in price. 
Table 1. Treatment effects on purchases

\begin{tabular}{|c|c|c|c|c|c|c|c|}
\hline \multirow{4}{*}{$\begin{array}{l}\text { Sample } \\
\text { Dependent variable }\end{array}$} & \multirow{3}{*}{$\begin{array}{c}\text { All } \\
\\
\begin{array}{c}\text { Buys a } \\
\text { refrigerator }\end{array}\end{array}$} & \multicolumn{6}{|c|}{ Buyers } \\
\hline & & \multicolumn{6}{|c|}{ Feature of refrigerator bought } \\
\hline & & $\begin{array}{c}\text { Energy } \\
\text { consumption } \\
(\mathbf{k W h}) \\
\end{array}$ & Price & $\begin{array}{c}\text { Total } \\
\text { cost }\end{array}$ & $\mathbf{A}+++$ & $\mathbf{A}++$ & A+ \\
\hline & (1) & (2) & (3) & (4) & (5) & (6) & $(7)$ \\
\hline \multicolumn{8}{|l|}{ Panel A } \\
\hline Treat & $\begin{array}{l}-0.001 \\
(0.001)\end{array}$ & $\begin{array}{c}1.890 \\
(2.050)\end{array}$ & $\begin{array}{l}-18.564 \\
(8.973)\end{array}$ & $\begin{array}{l}-11.422 \\
(12.794)\end{array}$ & $\begin{array}{l}-0.022 \\
(0.011)\end{array}$ & $\begin{array}{c}0.000 \\
(0.014)\end{array}$ & $\begin{array}{c}0.022 \\
(0.013)\end{array}$ \\
\hline Avg. Daily price $\mathrm{A}+++$ & $\begin{array}{l}-0.006 \\
(0.002)\end{array}$ & $\begin{array}{c}0.250 \\
(2.636)\end{array}$ & $\begin{array}{c}-9.596 \\
(11.529)\end{array}$ & $\begin{array}{l}-10.142 \\
(16.438)\end{array}$ & $\begin{array}{l}-0.042 \\
(0.013)\end{array}$ & $\begin{array}{c}0.007 \\
(0.017)\end{array}$ & $\begin{array}{c}0.034 \\
(0.018)\end{array}$ \\
\hline Avg. Daily price A++ & $\begin{array}{l}-0.008 \\
(0.002)\end{array}$ & $\begin{array}{c}2.158 \\
(3.214)\end{array}$ & $\begin{array}{c}32.351 \\
(14.065)\end{array}$ & $\begin{array}{c}41.527 \\
(20.053)\end{array}$ & $\begin{array}{c}0.007 \\
(0.017)\end{array}$ & $\begin{array}{l}-0.071 \\
(0.021)\end{array}$ & $\begin{array}{c}0.056 \\
(0.021)\end{array}$ \\
\hline Avg. Daily price A+ & $\begin{array}{c}0.004 \\
(0.003)\end{array}$ & $\begin{array}{c}8.978 \\
(4.016)\end{array}$ & $\begin{array}{c}60.524 \\
(17.570)\end{array}$ & $\begin{array}{c}87.401 \\
(25.050)\end{array}$ & $\begin{array}{c}0.051 \\
(0.021)\end{array}$ & $\begin{array}{c}0.057 \\
(0.027)\end{array}$ & $\begin{array}{l}-0.102 \\
(0.027)\end{array}$ \\
\hline Mean of dep var & 0.060 & 252.409 & 565.053 & 1322.165 & 0.175 & 0.418 & 0.395 \\
\hline Number of Obs & 128167 & 7631 & 7541 & 7541 & 7631 & 7631 & 7631 \\
\hline R-Squared & 0.029 & 0.184 & 0.220 & 0.211 & 0.145 & 0.175 & 0.181 \\
\hline \multicolumn{8}{|l|}{ Panel B } \\
\hline Treat 1-year & $\begin{array}{c}0.000 \\
(0.002)\end{array}$ & $\begin{array}{l}-0.356 \\
(2.364)\end{array}$ & $\begin{array}{l}-17.475 \\
(10.347)\end{array}$ & $\begin{array}{l}-17.323 \\
(14.751)\end{array}$ & $\begin{array}{l}-0.021 \\
(0.012)\end{array}$ & $\begin{array}{c}0.011 \\
(0.016)\end{array}$ & $\begin{array}{c}0.009 \\
(0.015)\end{array}$ \\
\hline Treat 15-year & $\begin{array}{l}-0.002 \\
(0.002)\end{array}$ & $\begin{array}{c}4.273 \\
(2.400)\end{array}$ & $\begin{array}{l}-19.722 \\
(10.514)\end{array}$ & $\begin{array}{c}-5.145 \\
(14.989)\end{array}$ & $\begin{array}{l}-0.022 \\
(0.013)\end{array}$ & $\begin{array}{l}-0.012 \\
(0.016)\end{array}$ & $\begin{array}{c}0.036 \\
(0.016)\end{array}$ \\
\hline Avg. Daily price A+++ & $\begin{array}{l}-0.006 \\
(0.002)\end{array}$ & $\begin{array}{c}0.213 \\
(2.635)\end{array}$ & $\begin{array}{c}-9.578 \\
(11.530)\end{array}$ & $\begin{array}{l}-10.236 \\
(16.438)\end{array}$ & $\begin{array}{l}-0.042 \\
(0.013)\end{array}$ & $\begin{array}{c}0.007 \\
(0.017)\end{array}$ & $\begin{array}{c}0.034 \\
(0.018)\end{array}$ \\
\hline Avg. Daily price A++ & $\begin{array}{l}-0.008 \\
(0.002)\end{array}$ & $\begin{array}{c}2.161 \\
(3.214)\end{array}$ & $\begin{array}{c}32.353 \\
(14.066)\end{array}$ & $\begin{array}{c}41.513 \\
(20.053)\end{array}$ & $\begin{array}{c}0.007 \\
(0.017)\end{array}$ & $\begin{array}{l}-0.071 \\
(0.021)\end{array}$ & $\begin{array}{c}0.056 \\
(0.021)\end{array}$ \\
\hline Avg. Daily price A+ & $\begin{array}{c}0.004 \\
(0.003)\end{array}$ & $\begin{array}{c}9.068 \\
(4.016)\end{array}$ & $\begin{array}{c}60.486 \\
(17.572)\end{array}$ & $\begin{array}{c}87.609 \\
(25.052)\end{array}$ & $\begin{array}{c}0.051 \\
(0.021)\end{array}$ & $\begin{array}{c}0.057 \\
(0.027)\end{array}$ & $\begin{array}{l}-0.102 \\
(0.027)\end{array}$ \\
\hline Mean of dep var & 0.060 & 252.409 & 565.053 & 1322.165 & 0.175 & 0.418 & 0.395 \\
\hline Number of Obs & 128167 & 7631 & 7541 & 7541 & 7631 & 7631 & 7631 \\
\hline R-Squared & 0.029 & 0.184 & 0.220 & 0.211 & 0.145 & 0.175 & 0.181 \\
\hline $\mathrm{p}$-value for test: $1-\mathrm{yr}=15-\mathrm{yr}$ & 0.120 & 0.055 & 0.832 & 0.421 & 0.919 & 0.156 & 0.093 \\
\hline Week f.e & Yes & Yes & Yes & Yes & Yes & Yes & Yes \\
\hline Municipality f.e. & Yes & Yes & Yes & Yes & Yes & Yes & Yes \\
\hline
\end{tabular}

Note: OLS regressions. Robust standard errors in parentheses. All regressions control for week and municipality fixed-effects. Panel A examines the impact of being treated, while Panel B distinguishes between the two treatments.

\section{Treatment effect on search patterns}

The results on purchases indicate that providing information on energy costs on top of the energy labels affected customers' choice of products. We exploit available data on the pages viewed by customers to 
study whether these different choices result from different search patterns induced by the treatments. This analysis's outcome variables are the number of refrigerator product pages viewed and the time spent browsing them.

While we observe no treatment effects on search outcomes for the full sample of users, in terms of total number of pages viewed or the time spent on them (Appendix Table A6), we find that the energy cost information deepens the search process among buyers, in terms of both alternatives considered and time spent examining them (Table 2). Treated customers view 2.2 more refrigerator pages and spend 188 more seconds searching, an increase of $5.2(\mathrm{p}<0.1)$ and $6.2 \%(\mathrm{p}<0.05)$ over the mean of the dependent variable, respectively. In both cases, the result is driven by the 15 -year treatment, with treatment effects significant at the $1 \%$ level for search time.

Disentangling these effects by energy class, we see that the increase in overall search depth and time is concentrated among products in lower energy classes. Treated subjects spend 102 and 98 seconds more on products in classes $\mathrm{A}++$ and $\mathrm{A}+$, respectively. This corresponds to a $7.7(\mathrm{p}<0.1)$ and $9.4 \%(\mathrm{p}<0.05)$ increase in time spent viewing refrigerators of energy class $\mathrm{A}++$ and $\mathrm{A}+$, respectively. As in the analysis of purchase decisions, these results are driven by the 15 -year treatment, which leads to an $11.9(\mathrm{p}<0.05)$ and $13.4 \%(\mathrm{p}<0.01)$ increase in products viewed and search time, respectively. ${ }^{22}$

Product prices do not appear to determine the choice of which products to view. Still, they do affect the time spent viewing products in different energy classes, a pattern consistent with that observed for product purchases.

Overall, the analysis of purchase and navigation outcomes paints a consistent picture: providing information on the energy cost of products increases the attention given by prospective buyers to lower efficiency products and the likelihood that these users eventually purchase such items.

22 Appendix Figure A8 shows marginal treatment effects on search time, and Table A6 shows that the results are robust to alternative definitions of the sample. 
Table 2. Treatment effects on search: buyers

\begin{tabular}{|c|c|c|c|c|c|c|c|c|}
\hline \multirow[t]{3}{*}{ Dependent variable } & \multicolumn{4}{|c|}{ Number of refrigerator pages viewed } & \multicolumn{4}{|c|}{ Number of seconds spent on refrige rators' pages } \\
\hline & All & A+++ & A++ & A+ & All & $\mathbf{A}+++$ & $\mathbf{A}++$ & $\mathbf{A +}$ \\
\hline & (1) & (2) & (3) & (4) & (5) & (6) & (7) & (8) \\
\hline \multicolumn{9}{|l|}{$\overline{P a n e l} A$} \\
\hline Treat & $\begin{array}{c}2.217 \\
(1.173)\end{array}$ & $\begin{array}{c}0.000 \\
(0.002)\end{array}$ & $\begin{array}{l}-0.010 \\
(0.008)\end{array}$ & $\begin{array}{c}0.036 \\
(0.018)\end{array}$ & $\begin{array}{l}188.334 \\
(88.235)\end{array}$ & $\begin{array}{l}-24.028 \\
(44.618)\end{array}$ & $\begin{array}{l}102.237 \\
(60.622)\end{array}$ & $\begin{array}{c}97.908 \\
(45.627)\end{array}$ \\
\hline Avg. Daily price A+++ & $\begin{array}{c}1.302 \\
(1.449)\end{array}$ & $\begin{array}{c}0.000 \\
(0.001)\end{array}$ & $\begin{array}{l}-0.001 \\
(0.005)\end{array}$ & $\begin{array}{l}-0.045 \\
(0.028)\end{array}$ & $\begin{array}{c}-64.320 \\
(103.570)\end{array}$ & $\begin{array}{l}-76.072 \\
(52.523)\end{array}$ & $\begin{array}{c}-8.278 \\
(69.586)\end{array}$ & $\begin{array}{c}44.092 \\
(55.723)\end{array}$ \\
\hline Avg. Daily price A++ & $\begin{array}{l}-1.444 \\
(1.943)\end{array}$ & $\begin{array}{c}0.004 \\
(0.003)\end{array}$ & $\begin{array}{c}0.008 \\
(0.007)\end{array}$ & $\begin{array}{c}0.061 \\
(0.048)\end{array}$ & $\begin{array}{l}-117.206 \\
(142.291)\end{array}$ & $\begin{array}{c}36.068 \\
(72.969)\end{array}$ & $\begin{array}{l}-143.195 \\
(93.698)\end{array}$ & $\begin{array}{l}-24.167 \\
(77.596)\end{array}$ \\
\hline Avg. Daily price A+ & $\begin{array}{l}-0.248 \\
(2.259)\end{array}$ & $\begin{array}{c}0.000 \\
(0.003)\end{array}$ & $\begin{array}{l}-0.000 \\
(0.010)\end{array}$ & $\begin{array}{l}-0.072 \\
(0.047)\end{array}$ & $\begin{array}{c}36.778 \\
(177.988)\end{array}$ & $\begin{array}{l}156.217 \\
(84.909)\end{array}$ & $\begin{array}{c}-12.815 \\
(120.565)\end{array}$ & $\begin{array}{l}-96.650 \\
(96.118)\end{array}$ \\
\hline Mean of dep var & 41.956 & 0.003 & 0.012 & 0.068 & 3037.892 & 582.905 & 1323.610 & 1043.708 \\
\hline Number of Obs & 7631 & 7631 & 7631 & 7631 & 7631 & 7631 & 7631 & 7631 \\
\hline R-Squared & 0.158 & 0.317 & 0.175 & 0.235 & 0.183 & 0.202 & 0.151 & 0.160 \\
\hline \multicolumn{9}{|l|}{ Panel B } \\
\hline Treat 1-year & $\begin{array}{c}1.370 \\
(1.319)\end{array}$ & $\begin{array}{l}-0.000 \\
(0.002)\end{array}$ & $\begin{array}{l}-0.011 \\
(0.007)\end{array}$ & $\begin{array}{c}0.036 \\
(0.023)\end{array}$ & $\begin{array}{c}96.047 \\
(99.911)\end{array}$ & $\begin{array}{l}-25.161 \\
(51.013)\end{array}$ & $\begin{array}{c}50.410 \\
(68.278)\end{array}$ & $\begin{array}{c}58.043 \\
(53.841)\end{array}$ \\
\hline Treat 15-year & $\begin{array}{c}3.116 \\
(1.469)\end{array}$ & $\begin{array}{c}0.001 \\
(0.002)\end{array}$ & $\begin{array}{l}-0.009 \\
(0.010)\end{array}$ & $\begin{array}{c}0.036 \\
(0.027)\end{array}$ & $\begin{array}{c}286.191 \\
(110.587)\end{array}$ & $\begin{array}{l}-22.827 \\
(53.312)\end{array}$ & $\begin{array}{l}157.193 \\
(75.810)\end{array}$ & $\begin{array}{l}140.179 \\
(54.526)\end{array}$ \\
\hline Avg. Daily price A+++ & $\begin{array}{c}1.288 \\
(1.449)\end{array}$ & $\begin{array}{c}0.000 \\
(0.001)\end{array}$ & $\begin{array}{l}-0.001 \\
(0.005)\end{array}$ & $\begin{array}{l}-0.045 \\
(0.028)\end{array}$ & $\begin{array}{c}-65.826 \\
(103.541)\end{array}$ & $\begin{array}{l}-76.091 \\
(52.462)\end{array}$ & $\begin{array}{c}-9.123 \\
(69.622)\end{array}$ & $\begin{array}{c}43.441 \\
(55.656)\end{array}$ \\
\hline Avg. Daily price A++ & $\begin{array}{l}-1.443 \\
(1.943)\end{array}$ & $\begin{array}{c}0.004 \\
(0.003)\end{array}$ & $\begin{array}{c}0.008 \\
(0.007)\end{array}$ & $\begin{array}{c}0.061 \\
(0.048)\end{array}$ & $\begin{array}{l}-117.102 \\
(142.269)\end{array}$ & $\begin{array}{c}36.069 \\
(72.972)\end{array}$ & $\begin{array}{l}-143.137 \\
(93.725)\end{array}$ & $\begin{array}{l}-24.122 \\
(77.585)\end{array}$ \\
\hline Avg. Daily price A+ & $\begin{array}{l}-0.215 \\
(2.257)\end{array}$ & $\begin{array}{c}0.000 \\
(0.003)\end{array}$ & $\begin{array}{l}-0.000 \\
(0.010)\end{array}$ & $\begin{array}{l}-0.072 \\
(0.047)\end{array}$ & $\begin{array}{c}40.470 \\
(177.823)\end{array}$ & $\begin{array}{l}156.262 \\
(84.841)\end{array}$ & $\begin{array}{c}-10.741 \\
(120.359)\end{array}$ & $\begin{array}{l}-95.055 \\
(96.259)\end{array}$ \\
\hline Mean of dep var & 41.956 & 0.003 & 0.012 & 0.068 & 3037.892 & 582.905 & 1323.610 & 1043.708 \\
\hline Number of Obs & 7631 & 7631 & 7631 & 7631 & 7631 & 7631 & 7631 & 7631 \\
\hline R-Squared & 0.158 & 0.317 & 0.175 & 0.235 & 0.183 & 0.202 & 0.151 & 0.160 \\
\hline $\mathrm{p}$-value for test: $1-\mathrm{yr}=15-\mathrm{yr}$ & 0.209 & 0.604 & 0.803 & 0.974 & 0.070 & 0.963 & 0.140 & 0.127 \\
\hline Week f.e & Yes & Yes & Yes & Yes & Yes & Yes & Yes & Yes \\
\hline Municipality f.e. & Yes & Yes & Yes & Yes & Yes & Yes & Yes & Yes \\
\hline
\end{tabular}

Note: OLS regressions in all columns. Robust standard errors in parentheses. All regressions control for week and municipality fixed-effects. Panel A examines the impact of being treated, while Panel B distinguishes between the two treatments.

\section{Conclusions}

Our analysis shows that providing information on energy-using appliances' energy costs, on top of the energy class and usage information included in the standard EU energy label, affects the energyefficiency class, but not the energy consumption in $\mathrm{kWh}$ and total cost of purchases. This result is consistent with consumers' overweighting energy class in their purchase decisions, possibly due to its salience within the standard energy label. The information on lifetime energy cost reduces the prominence of energy class and leads to fewer purchases among products in the highest efficiency class. The finding that treatments increase search time on low energy-efficacy class products also supports this interpretation. We find no evidence of imperfect information on electricity price among users since our treatments did not affect the total cost of products being purchased.

Overall, our results indicate that consumers rely on coarse signals when acquiring information. We find that the cost of this tendency in terms of the private economic efficiency of decisions is likely to be low, given the limited impact of providing simple but accurate cost information on the total cost of purchases. 
This result is encouraging from a policy perspective and supports the use of grading systems to help consumers understand complex and policy-relevant products' attributes. 


\section{References}

Abaluck, J., and Gruber, J. (2011). Choice inconsistencies among the elderly: evidence from plan choice in the Medicare Part D program. American Economic Review, 101(4), 1180-1210.

Abaluck, J., and Gruber, J. (2016). Evolving choice inconsistencies in choice of prescription drug insurance. American Economic Review, 106(8), 2145-84.

Allcott, H. (2013). The Welfare Effects of Misperceived Product Costs: Data and Calibrations from the Automobile Market. American Economic Journal: Economic Policy 5(3): 30-66.

Allcott, H. (2016). Paternalism and energy efficiency: an overview. Annual Review of Economics, 8, 145-176.

Allcott, H., and Greenstone, M. (2012). Is there an energy efficiency gap? Journal of Economic Perspectives, 26(1), 3-28.

Allcott, H., and Taubinsky D. (2015). Evaluating Behaviorally Motivated Policy: Experimental Evidence from the Lightbulb Market. American Economic Review 105(8): 2501-38.

Allcott, H., and Wozny, N. (2013). Gasoline Prices, Fuel Economy, and the Energy Paradox. The Review of Economics and Statistics 96(5): 779-95.

Bonan, J., Cattaneo, C., d'Adda, G., and Tavoni, M. (2019). Heterogeneity of Social Information Programs: The Role of Identity and Values. Centro Studi Luca d'Agliano, University of Milano.

Boogen, N., Daminato, C., Filippini, M. and Obrist, A. (2020). Can Information about Energy Costs Affect Consumers Choices? Evidence from a Field Experiment. CER-ETH Economics working paper series 20/334, CER-ETH - Center of Economic Research (CER-ETH) at ETH Zurich.

Bordalo, P., Gennaioli, N., and Shleifer, A. (2013). Salience and consumer choice. Journal of Political Economy 121(5): 803-843.

Caplin, A., and Dean, M. (2015). Revealed preference, rational inattention, and costly information acquisition. American Economic Review, 105(7), 2183-2203.

Chetty, R., Looney, A., and Kroft, K. (2009). Salience and Taxation: Theory and Evidence. American Economic Review 99(4): 1145-77.

Darden, M., and McCarthy, I.M. (2015). The Star Treatment Estimating the Impact of Star Ratings on Medicare Advantage Enrollments. Journal of Human Resources 50(4): 980-1008.

Davis, L.W., and Metcalf, G.E. (2016). Does Better Information Lead to Better Choices? Evidence from Energy-Efficiency Labels. Journal of the Association of Environmental and Resource Economists 3(3): 589-625.

DellaVigna, S. (2009). Psychology and Economics: Evidence from the Field. Journal of Economic Literature 47(2): 315-72. 
Deutsch, M. (2010a). Life Cycle Cost Disclosure, Consumer Behavior, and Business Implications. Journal of Industrial Ecology 14(1): 103-20.

(2010b). The Effect of Life-Cycle Cost Disclosure on Consumer Behavior: Evidence from a Field Experiment with Cooling Appliances. Energy Efficiency 3(4): 303-15.

Dranove, D, and Jin G.Z. (2010). Quality Disclosure and Certification: Theory and Practice. Journal of Economic Literature 48(4): 935-63.

Gerarden, T., Newell, R. G., and Stavins, R. N. (2015). Deconstructing the energy-efficiency gap: conceptual frameworks and evidence. American Economic Review, 105(5), 183-86.

Gerarden, T. D., Newell, R. G., and Stavins, R. N. (2017). Assessing the energy-efficiency gap. Journal of Economic Literature, 55(4), 1486-1525.

Gillingham, K., Newell, R. G., and Palmer, K. (2009). Energy efficiency economics and policy. Annu. Rev. Resour. Econ., 1(1), 597-620.

Gillingham, K., and Palmer, K. (2014). Bridging the energy efficiency gap: Policy insights from economic theory and empirical evidence. Review of Environmental Economics and Policy, 8(1), 18-38.

Guiso, L., Sapienza, P., and Zingales, L. (2016). Long-Term Persistence. Journal of the European Economic Association 14(6): 1401-36.

Hausman, J. A. (1979). Individual discount rates and the purchase and utilization of energy-using durables. The Bell Journal of Economics, 33-54.

Houde, S. (2018a). How Consumers Respond to Product Certification and the Value of Energy Information. The RAND Journal of Economics 49(2): 453-77. (2018b). The incidence of coarse certification: Evidence from the ENERGY STAR Program. CER-ETH-Center of Economic Research at ETH Zurich, Working Paper 18: 290.

Jorion, P., Liu, Z., and Shi, C. (2005). Informational Effects of Regulation FD: Evidence from Rating Agencies. Journal of Financial Economics 76(2): 309-30.

Larrick, R.P., and Soll, J.B. (2008). The MPG Illusion. Science 320(5883): 1593-94.

Newell, R.G., and Siikamäki, J. (2014). Nudging Energy Efficiency Behavior: The Role of Information Labels. Journal of the Association of Environmental and Resource Economists 1(4): 555-98.

Sallee, J.M. (2014). "Rational Inattention and Energy Efficiency." Journal of Law and Economics, Vol. 57(3) 781-820.

Sammer, K., and Wüstenhagen, R. (2006). The Influence of Eco-Labelling on Consumer Behaviour Results of a Discrete Choice Analysis for Washing Machines. Business Strategy and the Environment 15(3): 185-99. 


\section{Appendix A: Table and Figures}

\section{Figure A1. Listing page}

a. Control

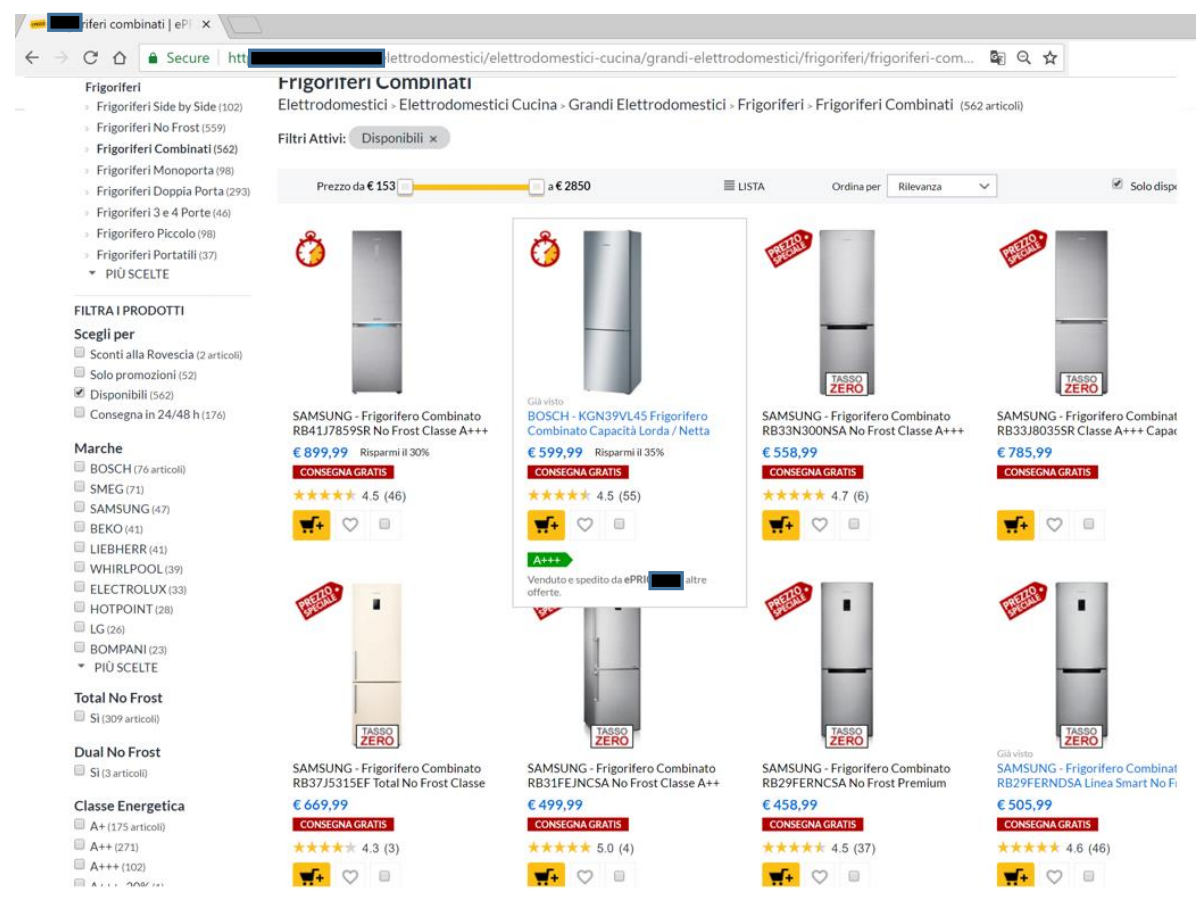

b. 1-year condition

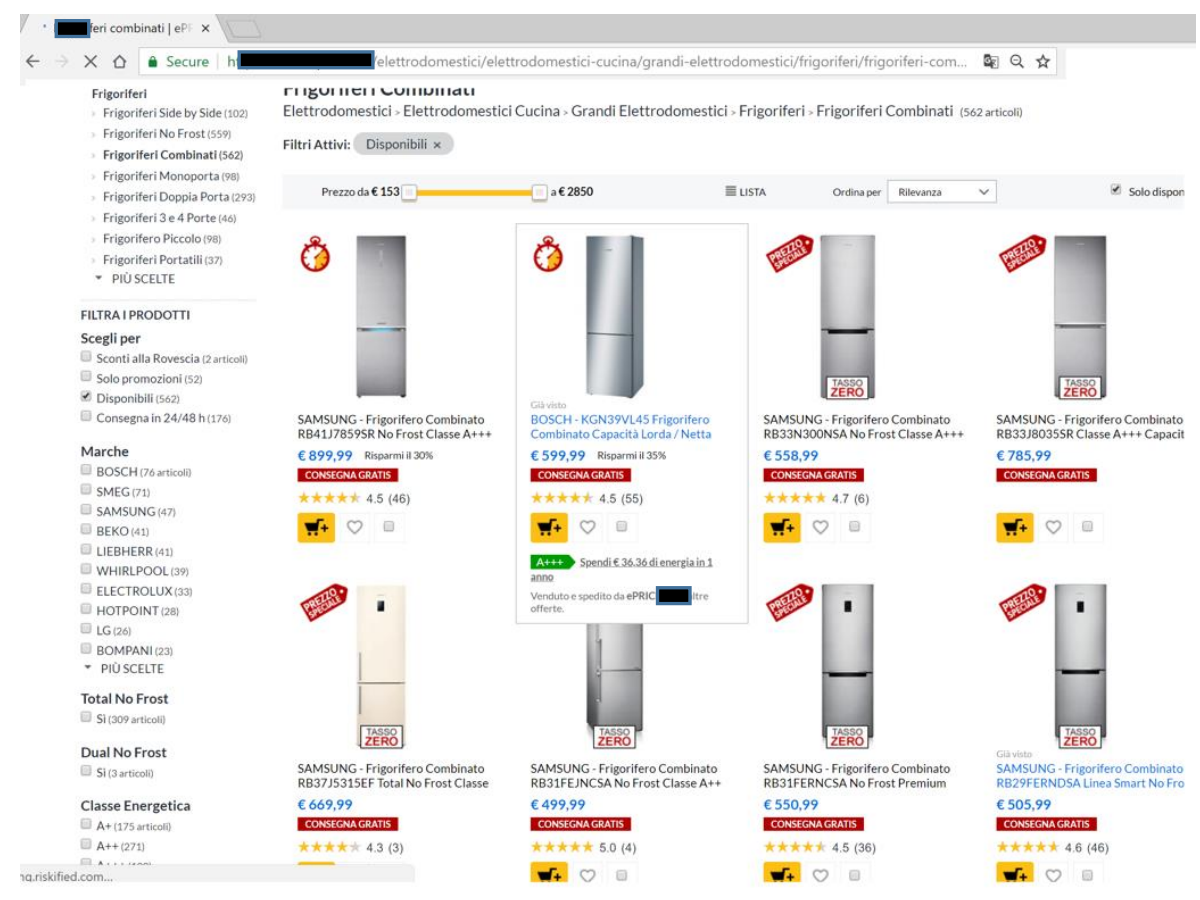




\section{c. 15-year Condition}

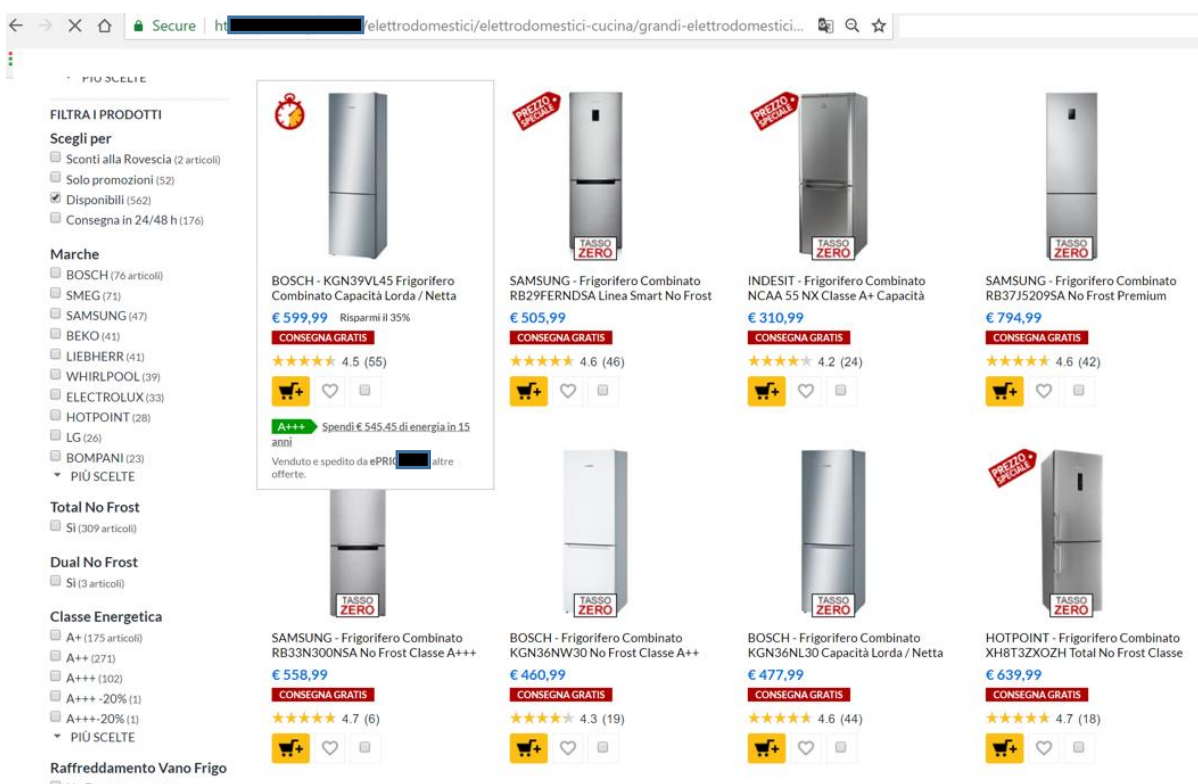


Figure A2. Product page

a. Control

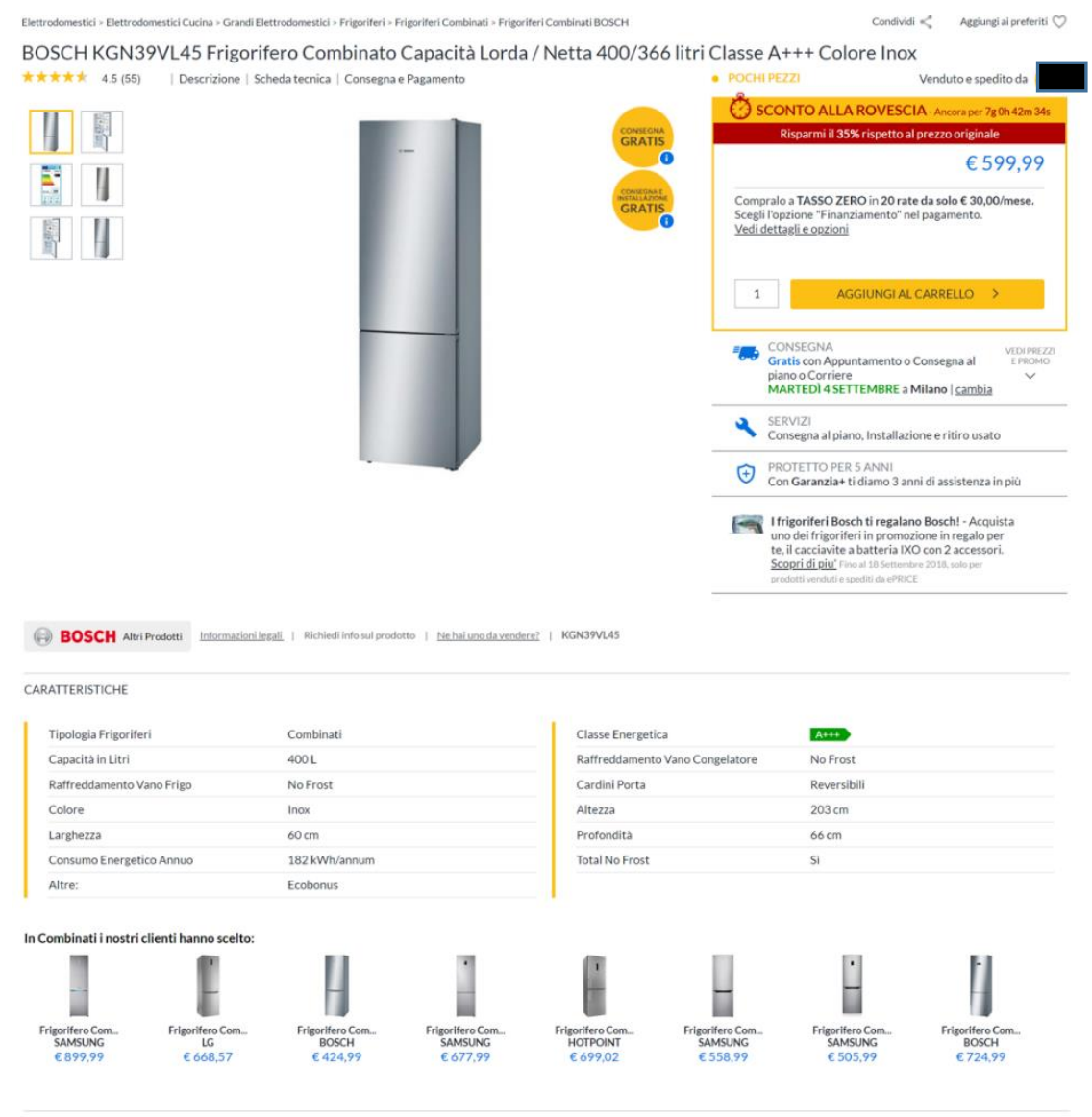

b. 1-year condition

$\begin{array}{ll}\text { Classe Energetica } & \text { At++ } \underline{\text { Spendi } € 36,36 \text { di energia in } 1 \text { anno }} \\ \text { Raffreddamento Vano Congelatore } & \text { No Frost } \\ \text { Cardini Porta } & \text { Reversibili } \\ \text { Altezza } & 203 \mathrm{~cm} \\ \text { Profondità } & 66 \mathrm{~cm} \\ \text { Total No Frost } & \text { Si }\end{array}$


c. 15-year condition

\begin{tabular}{ll} 
Classe Energetica & A+++ Spendi $€ 545,45$ di energia in 15 anni \\
\hline Raffreddamento Vano Congelatore & No Frost \\
\hline Cardini Porta & Reversibili \\
\hline Altezza & $203 \mathrm{~cm}$ \\
\hline Profondità & $66 \mathrm{~cm}$ \\
Total No Frost & Si
\end{tabular}

Figure A3. Pop-up

a. 1-year condition

Costo del consumo di energia elettrica del prodotto

II consumo energetico annuo del prodottoe contenuto nell 'letichetta energetica, ed é valorizzato sulla base del prezzo del
kWh per una famiglia tipo (contratto di maggior tutela, consumi annui di $2.700 \mathrm{kWh}$ e potenza impegnata di $3 \mathrm{~kW}$. pari

0.1998E (fonte: dati ARERA, secondo trimestre 20182).

Con questo prodotto classe $\mathrm{A}+++$

in 1 anno spendi

\section{$€ 36,36$}

CHIUDIE PROSEGUI CONGLIACQUISTI

In collaborazione con il progetto COBHAM del Politecnico di Milano ${ }^{4}$

\section{${ }^{2}$ Sito ARERA
${ }^{3}$ Sito Enea}

b. 15-year condition

Costo del consumo di energia elettrica del prodotto

II consumo energetico annuo del prodotto é contenuto nelletichetta energetica, ed è val orizzato sull a base del prezzo ode 0.19986 (fonte: dati ARERA secondo trimestre $2018^{2}$ ).
vita media di un trigoriferoe stimata pari a 15 anni (fonte: ENEA

Con questo prodotto classe $\mathrm{A}+++$

in 15 anni spendi

\section{$€ 545,45$}

In collaborazione con il progetto COBHAM del Politecnico di Milano ${ }^{4}$ 
Figure A4. Variation in prices over the study period

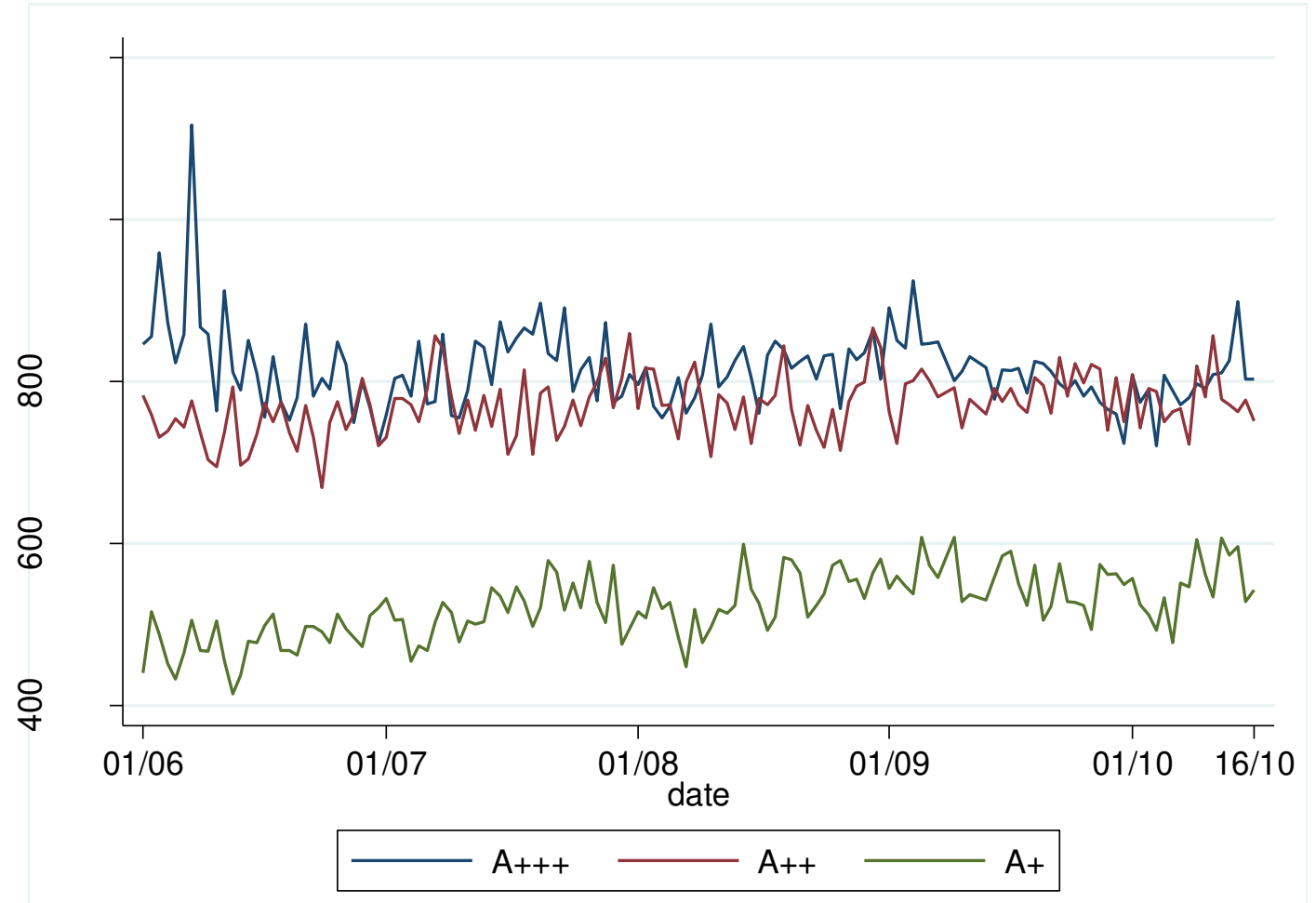

Note: The vertical axis expresses prices in euro. Average daily prices are defined as the average price of products viewed on each day. 


\section{Figure A5. Distribution of total cost of purchases}

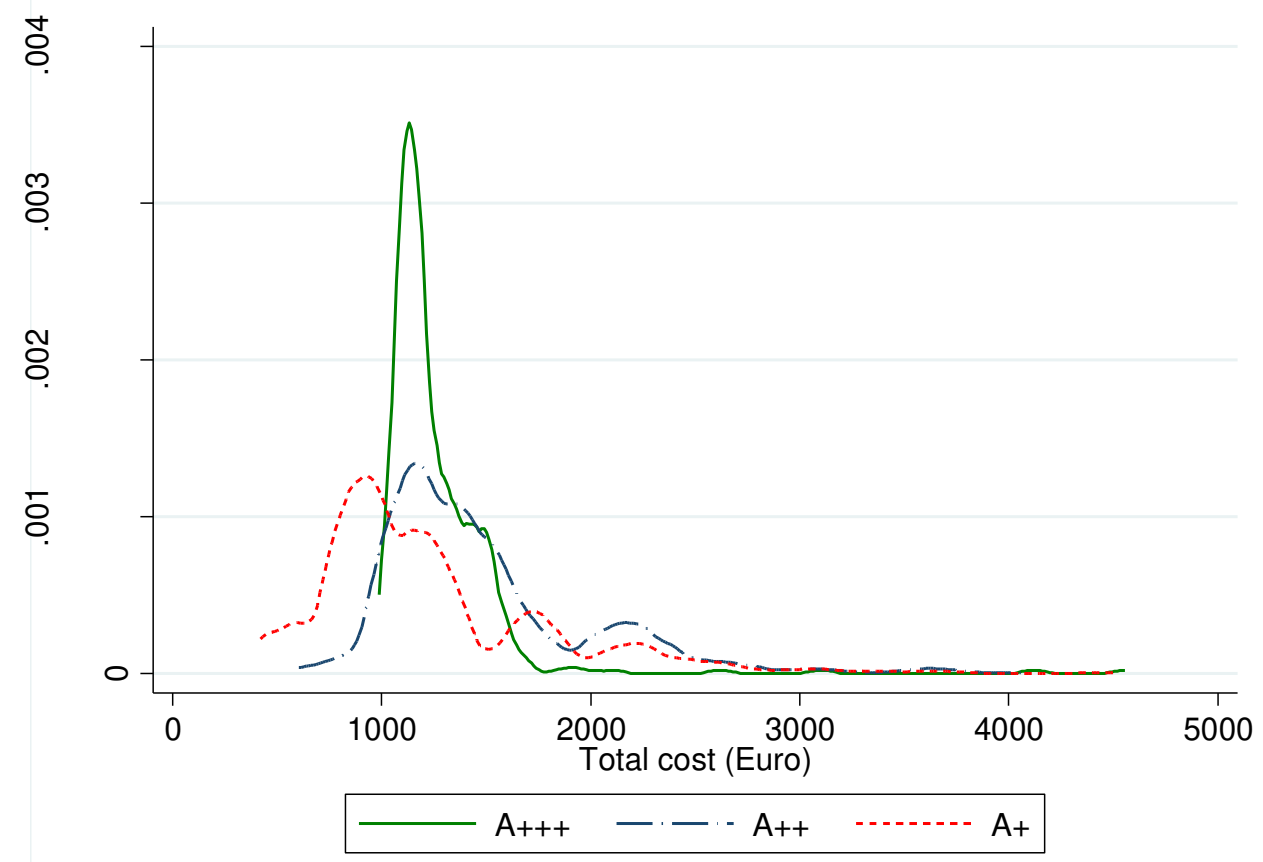

Note: kernel density of total cost of purchases, where total cost is defined as the sum of the price and of the undiscounted lifetime energy cost, by energy class. 
Figure A6. Marginal treatment effects: characteristics of purchases
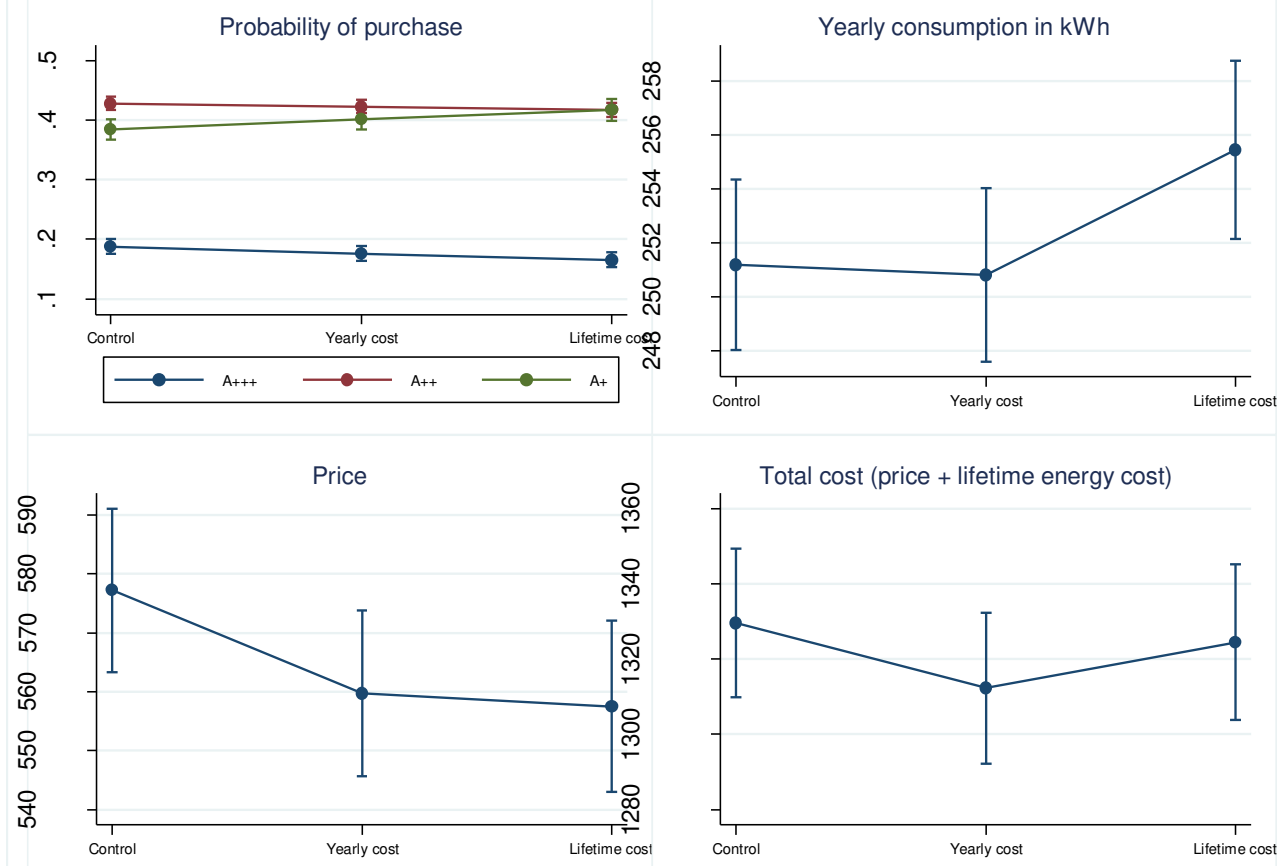

Notes: marginal treatment effects, computed from the coefficients of equation (1). Price and total cost are expressed in euro. 
Figure A7. Distribution of lifetime energy costs, price and total cost of purchases, by treatment
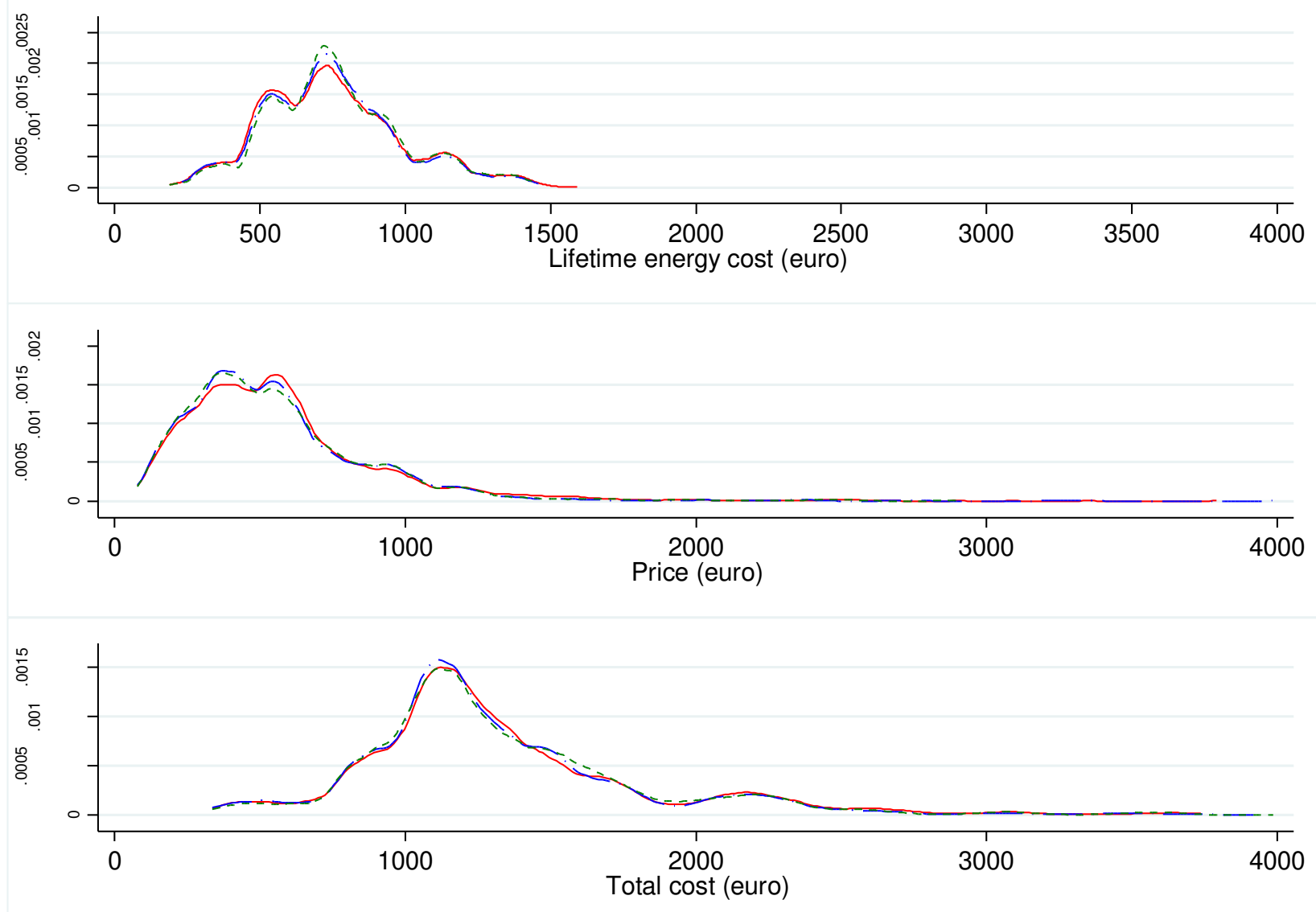

$$
\text { Control }-\cdots 1 \mathrm{yr} \cdots \cdots \mathrm{yr}
$$

Note: kernel density of undiscounted lifetime energy cost, price and total cost of purchases, where total cost is defined as the sum of the price and of the undiscounted lifetime energy cost, by treatment. 
Figure A8. Marginal treatment effects: search behavior
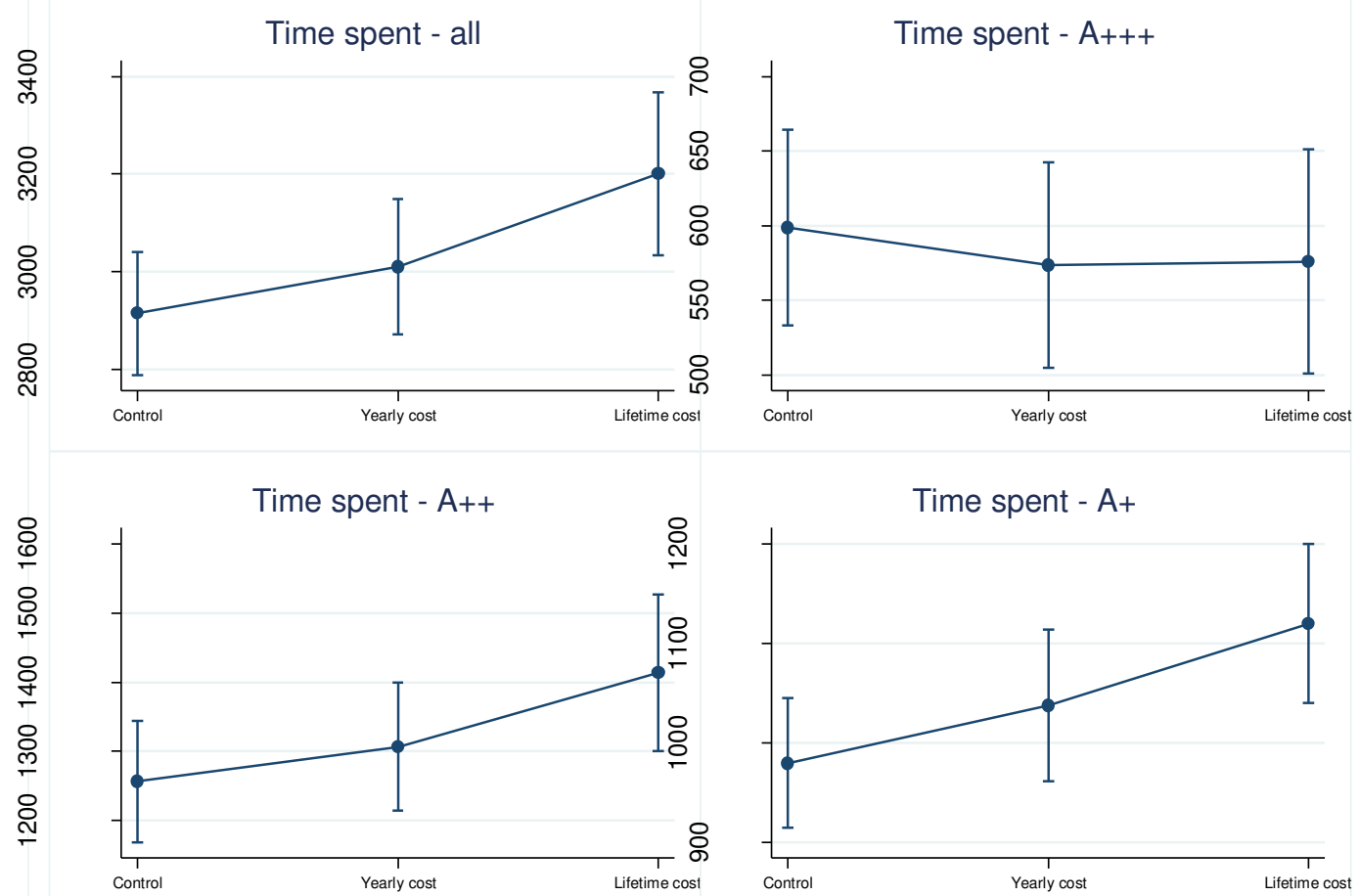

Time spent - A+

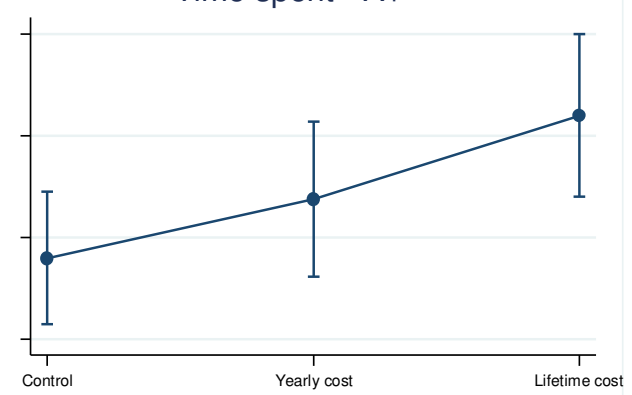

Notes: marginal treatment effects, computed from the coefficients of equation (1). Price and total cost are expressed in euro. 
Table A1. Price of refrigerators

\begin{tabular}{ll}
\hline & Mean (sd) \\
\hline Avg. daily price & 660.04 \\
& $(29.83)$ \\
& 815.66 \\
Avg. Daily price A+++ & $(48.61)$ \\
& 770.34 \\
Avg. Daily price A++ & $(37.07)$ \\
& 522.57 \\
Avg. Daily price A+ & $(40.85)$ \\
& 107.24 \\
Weekly variation in price A+++ & $(65.16)$ \\
& 87.40 \\
Weekly variation in price A++ & $(29.29)$ \\
& 71.22 \\
Weekly variation in price A+ & $(16.45)$ \\
\hline
\end{tabular}

Note: all values are expressed in euro. Standard deviations in parentheses. Average daily prices are defined as the average price of products viewed on each day. Averages displayed in the table are computed over the study period (June $1^{\text {st }}$-Oct $16^{\text {th }}$ ).

Table A2. Summary statistics of users' characteristics and balance test

\begin{tabular}{lcc}
\hline & Mean & p-value \\
& $(\mathbf{1})$ & $\mathbf{( 2 )}$ \\
\hline User placed another (non-refrigerator) order & 0.0441 & 0.6745 \\
Number of other (non-refrigerator) orders placed & 0.0734 & 0.8980 \\
User ordered more than one refrigerator & 0.0400 & 0.2714 \\
Municipality's population (/10000) & 0.6766 & 0.3838 \\
North East & 0.0933 & 0.6438 \\
North West & 0.3919 & 0.8237 \\
Center & 0.2885 & 0.1777 \\
South & 0.1329 & 0.1882 \\
Islands & 0.0627 & 0.3694 \\
Municipality's per capita income (euro) & 12,919 & 0.1799 \\
Frequency of municipality's population with high school diploma & 0.2877 & 0.6076 \\
Frequency of municipality's population with undergraduate degree & 0.1107 & 0.6019 \\
Frequency of municipality's population in the labor force & 0.4978 & 0.1308 \\
Frequency of municipality's labor force employed & 0.4495 & 0.1982 \\
\hline Note: Column 2 reports the p-value of a joint test of the null hypothesis that beta(1-year treatment) = beta(15-year \\
treatment) = 0, from a regression of users' characteristics on treatment dummies and date fixed-effects. Regressing \\
treatment status on the full set of individual traits yields an F-statistics of joint significance of the regressors equal to \\
1.12, thus indicating a low predictive power of covariates for treatment status.
\end{tabular}


Table A3. Summary statistics of users' behavior

\begin{tabular}{|c|c|c|}
\hline & $\begin{array}{c}\text { Mean } \\
\text { (1) }\end{array}$ & $\begin{array}{l}\text { S.d. } \\
\text { (2) }\end{array}$ \\
\hline Register/Log-in & 0.1974 & $(0.3980)$ \\
\hline Buy a refrigerator & 0.0595 & $(0.2366)$ \\
\hline Number of refrigerator pages viewed & 10.1253 & $(20.8434)$ \\
\hline Non-buyers & 8.1018 & $(16.2675)$ \\
\hline Buyers & 42.0977 & $(45.0660)$ \\
\hline Time spent viewing refrigerator pages (seconds) & 734.1172 & $(1752.428)$ \\
\hline Non-buyers & 587.102 & $(1448.952)$ \\
\hline Buyers & 3057.059 & $(3561.739)$ \\
\hline Number of products added to favorites & 0.0373 & $(0.4097)$ \\
\hline Non-buyers & 0.0277 & $(0.3456)$ \\
\hline Buyers & 0.1886 & $(0.9537)$ \\
\hline Number of products added to cart & 0.2270 & $(0.7109)$ \\
\hline Non-buyers & 0.1507 & $(0.5550)$ \\
\hline Buyers & 1.4327 & $(1.4410)$ \\
\hline Click on energy cost information pop-up & 0.0079 & $(0.1007)$ \\
\hline Non-buyers & 0.0073 & $(0.0966)$ \\
\hline Buyers & 0.0170 & $(0.1518)$ \\
\hline
\end{tabular}

Note: standard deviations in parentheses (Column 2). 
Table A4. Treatment effect on purchase decisions: robustness checks

\begin{tabular}{|c|c|c|c|c|c|c|c|c|c|}
\hline \multirow{3}{*}{$\begin{array}{l}\text { Sample } \\
\text { Dependent variable: fe ature } \\
\text { of refrige rator bought }\end{array}$} & \multicolumn{3}{|c|}{ All users } & \multicolumn{3}{|c|}{$\begin{array}{c}\text { Buyers (excl. multiple } \\
\text { tre atments) }\end{array}$} & \multicolumn{3}{|c|}{$\begin{array}{c}\text { Buyers (excl. multiple } \\
\text { purchases) }\end{array}$} \\
\hline & $\mathbf{A}+++$ & $\mathbf{A}++$ & $A+$ & $\mathrm{A}+++$ & $\mathrm{A}++$ & $\mathbf{A}+$ & $\mathrm{A}+++$ & $\mathbf{A}++$ & $\mathbf{A +}$ \\
\hline & (1) & $(2)$ & (3) & (4) & (5) & (6) & $(7)$ & $(8)$ & (9) \\
\hline \multicolumn{10}{|l|}{ Panel A } \\
\hline Treat & $\begin{array}{l}-0.002 \\
(0.001)\end{array}$ & $\begin{array}{c}0.000 \\
(0.001)\end{array}$ & $\begin{array}{c}0.001 \\
(0.001)\end{array}$ & $\begin{array}{l}-0.018 \\
(0.012)\end{array}$ & $\begin{array}{l}-0.008 \\
(0.015)\end{array}$ & $\begin{array}{c}0.027 \\
(0.015)\end{array}$ & $\begin{array}{l}-0.023 \\
(0.011)\end{array}$ & $\begin{array}{c}0.001 \\
(0.014)\end{array}$ & $\begin{array}{c}0.023 \\
(0.014)\end{array}$ \\
\hline Mean of dep var & 0.010 & 0.025 & 0.023 & 0.167 & 0.416 & 0.403 & 0.176 & 0.418 & 0.393 \\
\hline Number of Obs & 128167 & 128167 & 128167 & 6318 & 6318 & 6318 & 7341 & 7341 & 7341 \\
\hline R-Squared & 0.018 & 0.028 & 0.030 & 0.156 & 0.192 & 0.194 & 0.147 & 0.176 & 0.181 \\
\hline \multicolumn{10}{|l|}{ Panel B } \\
\hline Treat 1-year & $\begin{array}{l}-0.001 \\
(0.001)\end{array}$ & $\begin{array}{c}0.001 \\
(0.001)\end{array}$ & $\begin{array}{c}0.001 \\
(0.001)\end{array}$ & $\begin{array}{l}-0.015 \\
(0.014)\end{array}$ & $\begin{array}{c}0.009 \\
(0.017)\end{array}$ & $\begin{array}{c}0.006 \\
(0.017)\end{array}$ & $\begin{array}{l}-0.024 \\
(0.013)\end{array}$ & $\begin{array}{c}0.015 \\
(0.016)\end{array}$ & $\begin{array}{c}0.009 \\
(0.016)\end{array}$ \\
\hline Treat 15 -year & $\begin{array}{l}-0.002 \\
(0.001)\end{array}$ & $\begin{array}{l}-0.001 \\
(0.001)\end{array}$ & $\begin{array}{c}0.001 \\
(0.001)\end{array}$ & $\begin{array}{l}-0.021 \\
(0.014)\end{array}$ & $\begin{array}{l}-0.027 \\
(0.018)\end{array}$ & $\begin{array}{c}0.049 \\
(0.018)\end{array}$ & $\begin{array}{l}-0.023 \\
(0.013)\end{array}$ & $\begin{array}{l}-0.013 \\
(0.016)\end{array}$ & $\begin{array}{c}0.038 \\
(0.016)\end{array}$ \\
\hline Mean of dep var & 0.010 & 0.025 & 0.023 & 0.167 & 0.416 & 0.403 & 0.176 & 0.418 & 0.393 \\
\hline Number of Obs & 128167 & 128167 & 128167 & 6318 & 6318 & 6318 & 7341 & 7341 & 7341 \\
\hline R-Squared & 0.018 & 0.028 & 0.030 & 0.156 & 0.192 & 0.195 & 0.147 & 0.176 & 0.182 \\
\hline Price controls & Yes & Yes & Yes & Yes & Yes & Yes & Yes & Yes & Yes \\
\hline Week f.e & Yes & Yes & Yes & Yes & Yes & Yes & Yes & Yes & Yes \\
\hline Municipality f.e. & Yes & Yes & Yes & Yes & Yes & Yes & Yes & Yes & Yes \\
\hline
\end{tabular}

Note: OLS regressions in all columns. Robust standard errors in parentheses. All regressions control for the average daily prices of refrigerators in classes $\mathrm{A}+++, \mathrm{A}++$ and $\mathrm{A}+$; and for week and municipality fixed-effects. Columns 1 to 3 report results for all users, regardless of whether they made a purchase or not; Columns 4 to 6 report results for the sample of buyers, excluding those who were exposed to multiple treatments; Columns 7 to 9 report results for the sample of buyers, excluding those who made multiple purchases. 
Table A5. Treatment effects on purchased refrigerators' capacity

Dependent variable

(1)

(1)

$$
-2.366
$$

Treat 1-year

Treat 15-year

Mean of dep var

Number of Obs

R-Squared

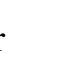


Table A6. Treatment effect on search outcomes: robustness checks

\begin{tabular}{|c|c|c|c|c|c|c|c|c|}
\hline \multirow[t]{3}{*}{ Dependent variable } & \multicolumn{4}{|c|}{$\begin{array}{c}\text { Number of refrige rator pages } \\
\text { vie wed }\end{array}$} & \multicolumn{4}{|c|}{$\begin{array}{c}\text { Number of seconds spent on } \\
\text { refrige rators' pages }\end{array}$} \\
\hline & All & $\mathbf{A + + +}$ & $\mathbf{A + +}$ & $\mathbf{A +}$ & All & $\mathbf{A + + +}$ & $\mathbf{A}++$ & $\mathbf{A +}$ \\
\hline & (1) & (2) & (3) & (4) & (5) & (6) & (7) & (8) \\
\hline \multicolumn{9}{|c|}{ Panel A: sample $=$ all users } \\
\hline Treat & $\begin{array}{c}0.083 \\
(0.120)\end{array}$ & $\begin{array}{c}0.001 \\
(0.001)\end{array}$ & $\begin{array}{l}-0.001 \\
(0.001)\end{array}$ & $\begin{array}{c}0.000 \\
(0.004)\end{array}$ & $\begin{array}{c}0.738 \\
(9.922)\end{array}$ & $\begin{array}{l}-4.712 \\
(3.814)\end{array}$ & $\begin{array}{c}0.113 \\
(5.477)\end{array}$ & $\begin{array}{c}6.711 \\
(4.636)\end{array}$ \\
\hline Treat 1-year & $\begin{array}{c}0.158 \\
(0.138)\end{array}$ & $\begin{array}{c}0.002 \\
(0.001)\end{array}$ & $\begin{array}{l}-0.001 \\
(0.001)\end{array}$ & $\begin{array}{c}0.002 \\
(0.004)\end{array}$ & $\begin{array}{c}5.413 \\
(11.241)\end{array}$ & $\begin{array}{l}-3.594 \\
(4.330)\end{array}$ & $\begin{array}{c}1.773 \\
(6.278)\end{array}$ & $\begin{array}{c}8.731 \\
(5.349)\end{array}$ \\
\hline Treat 15-year & $\begin{array}{c}0.006 \\
(0.145)\end{array}$ & $\begin{array}{l}-0.000 \\
(0.001)\end{array}$ & $\begin{array}{l}-0.002 \\
(0.001)\end{array}$ & $\begin{array}{l}-0.002 \\
(0.004)\end{array}$ & $\begin{array}{c}-4.015 \\
(11.956)\end{array}$ & $\begin{array}{l}-5.849 \\
(4.495)\end{array}$ & $\begin{array}{l}-1.574 \\
(6.483)\end{array}$ & $\begin{array}{c}4.658 \\
(5.520)\end{array}$ \\
\hline \multicolumn{9}{|c|}{ Panel B: sample $=$ buyers $($ excl. multiple treatments $)$} \\
\hline Treat & $\begin{array}{c}0.817 \\
(1.081)\end{array}$ & $\begin{array}{c}0.001 \\
(0.002)\end{array}$ & $\begin{array}{l}-0.014 \\
(0.009)\end{array}$ & $\begin{array}{c}0.021 \\
(0.019)\end{array}$ & $\begin{array}{l}111.686 \\
(87.300)\end{array}$ & $\begin{array}{c}-25.359 \\
(43.314)\end{array}$ & $\begin{array}{c}20.262 \\
(61.120)\end{array}$ & $\begin{array}{l}115.675 \\
(47.287)\end{array}$ \\
\hline Treat 1-year & $\begin{array}{c}0.870 \\
(1.259)\end{array}$ & $\begin{array}{c}0.001 \\
(0.002)\end{array}$ & $\begin{array}{l}-0.013 \\
(0.008)\end{array}$ & $\begin{array}{c}0.016 \\
(0.021)\end{array}$ & $\begin{array}{c}85.543 \\
(101.023)\end{array}$ & $\begin{array}{c}7.306 \\
(51.530)\end{array}$ & $\begin{array}{c}4.686 \\
(69.455)\end{array}$ & $\begin{array}{c}68.884 \\
(55.952)\end{array}$ \\
\hline Treat 15-year & $\begin{array}{c}0.760 \\
(1.283)\end{array}$ & $\begin{array}{c}0.001 \\
(0.002)\end{array}$ & $\begin{array}{l}-0.015 \\
(0.011)\end{array}$ & $\begin{array}{c}0.026 \\
(0.029)\end{array}$ & $\begin{array}{c}139.634 \\
(105.682)\end{array}$ & $\begin{array}{l}-60.282 \\
(48.274)\end{array}$ & $\begin{array}{c}36.914 \\
(74.639)\end{array}$ & $\begin{array}{r}165.698 \\
(56.775)\end{array}$ \\
\hline \multicolumn{9}{|c|}{ Panel C: sample = buyers $($ excl. multiple purchases $)$} \\
\hline Treat & $\begin{array}{c}2.237 \\
(1.116)\end{array}$ & $\begin{array}{l}-0.001 \\
(0.002)\end{array}$ & $\begin{array}{l}-0.014 \\
(0.008)\end{array}$ & $\begin{array}{c}0.033 \\
(0.018)\end{array}$ & $\begin{array}{r}175.020 \\
(84.516)\end{array}$ & $\begin{array}{l}-37.872 \\
(44.111)\end{array}$ & $\begin{array}{l}107.906 \\
(60.173)\end{array}$ & $\begin{array}{c}95.216 \\
(44.436)\end{array}$ \\
\hline Treat 1-year & $\begin{array}{c}1.888 \\
(1.269)\end{array}$ & $\begin{array}{l}-0.001 \\
(0.002)\end{array}$ & $\begin{array}{l}-0.014 \\
(0.007)\end{array}$ & $\begin{array}{c}0.026 \\
(0.022)\end{array}$ & $\begin{array}{l}129.449 \\
(96.821)\end{array}$ & $\begin{array}{l}-35.486 \\
(50.808)\end{array}$ & $\begin{array}{c}89.772 \\
(68.180)\end{array}$ & $\begin{array}{c}65.434 \\
(53.378)\end{array}$ \\
\hline Treat 15-year & $\begin{array}{c}2.608 \\
(1.396)\end{array}$ & $\begin{array}{c}0.000 \\
(0.002)\end{array}$ & $\begin{array}{l}-0.014 \\
(0.010)\end{array}$ & $\begin{array}{c}0.041 \\
(0.027)\end{array}$ & $\begin{array}{c}223.552 \\
(105.232)\end{array}$ & $\begin{array}{l}-40.414 \\
(52.634)\end{array}$ & $\begin{array}{r}127.218 \\
(74.981)\end{array}$ & $\begin{array}{r}126.934 \\
(51.584)\end{array}$ \\
\hline Price controls & Yes & Yes & Yes & Yes & Yes & Yes & Yes & Yes \\
\hline Week f.e & Yes & Yes & Yes & Yes & Yes & Yes & Yes & Yes \\
\hline Municipality f.e. & Yes & Yes & Yes & Yes & Yes & Yes & Yes & Yes \\
\hline
\end{tabular}

Note: OLS regressions in all columns. Robust standard errors in parentheses. All regressions control for the average daily prices of refrigerators in classes $\mathrm{A}+++, \mathrm{A}++$ and $\mathrm{A}+$; and for week and municipality fixed-effects. Panel A reports results for all users, regardless of whether they made a purchase or not; Panel B for the sample of buyers, excluding those who were exposed to multiple treatments; Panel $\mathrm{C}$ for the sample of buyers, excluding those who made multiple purchases. In each panel, we report the results of two separate regressions: the first is a regression of the outcome on a dummy equal to 1 for being treated; the second on each treatment dummy separately. 
Figures

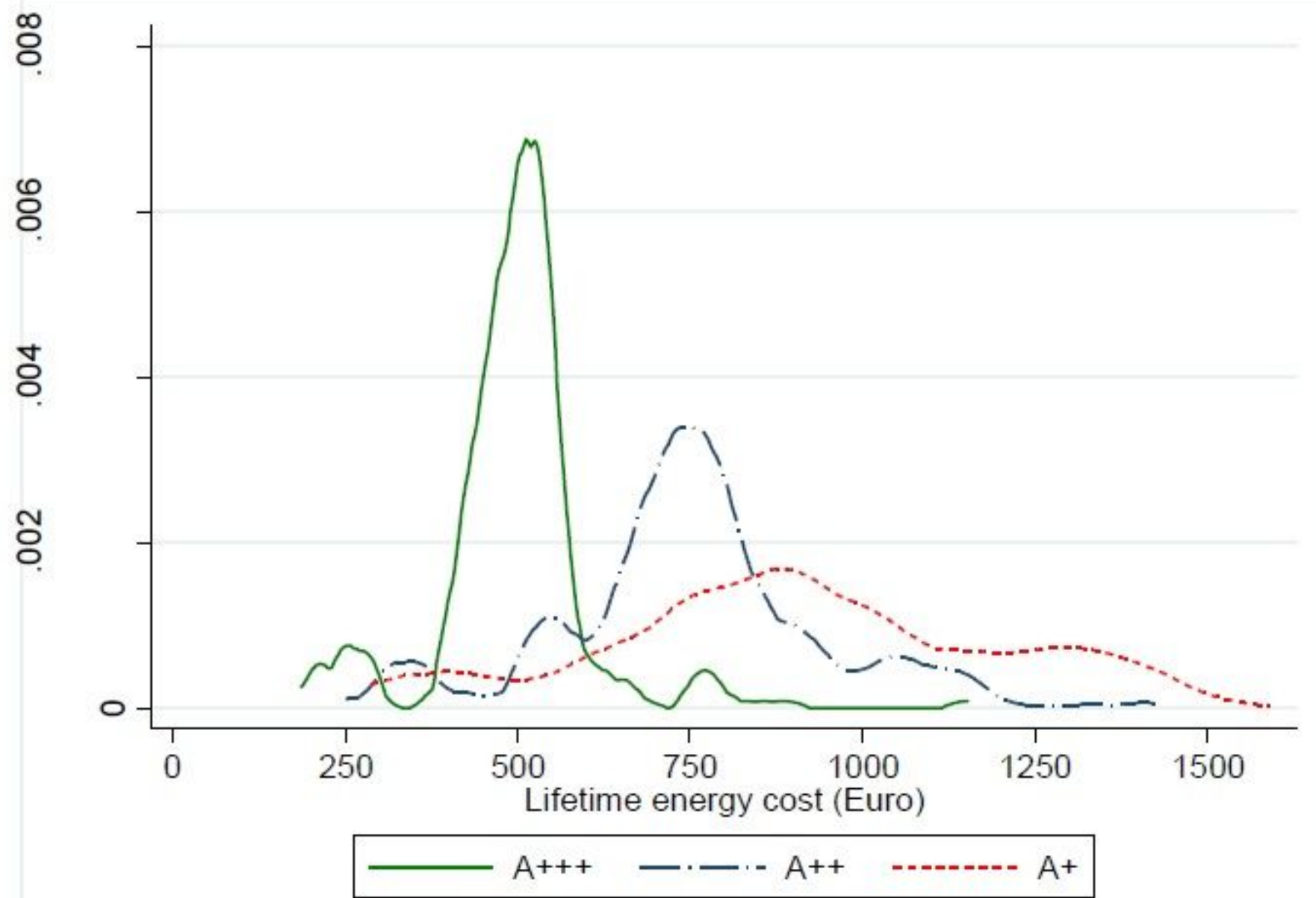

\section{Figure 1}

Refrigerators' lifetime energy cost. Note: the graph presents the kernel density of lifetime, i.e., 15-year, energy costs of refrigerators included in the retailer's catalogue, by energy class.

\section{Supplementary Files}

This is a list of supplementary files associated with this preprint. Click to download.

- energyawarenessonlineapp20201005.pdf 